\title{
Environmental forcing of phytoplankton community structure and function in the Canadian High Arctic: contrasting oligotrophic and eutrophic regions
}

\author{
Mathieu Ardyna ${ }^{1,5, *}$, Michel Gosselin ${ }^{1}$, Christine Michel $^{2}$, Michel Poulin $^{3}$, \\ Jean-Éric Tremblay ${ }^{4}$ \\ ${ }^{1}$ Institut des sciences de la mer de Rimouski, Université du Québec à Rimouski, 310 Allée des Ursulines, Rimouski, \\ Québec G5L 3A1, Canada \\ ${ }^{2}$ Freshwater Institute, Fisheries and Oceans Canada, 501 University Crescent, Winnipeg, Manitoba R3T 2N6, Canada \\ ${ }^{3}$ Research Division, Canadian Museum of Nature, PO Box 3443, Station D, Ottawa, Ontario K1P 6P4, Canada \\ ${ }^{4}$ Département de biologie et Québec-Océan, Université Laval, Québec, Québec G1V 0A6, Canada \\ ${ }^{5}$ Present address: Takuvik Joint International Laboratory, Laval University (Canada) - CNRS (France), \\ Département de biologie et Québec-Océan, Université Laval, Québec, Québec G1V 0A6, Canada
}

\begin{abstract}
We assessed phytoplankton dynamics and its environmental control across the Canadian High Arctic (CHA). Environmental (hydrographic, atmospheric, sea ice conditions) and biological variables (phytoplankton production, biomass, composition) were measured along $3500 \mathrm{~km}$ transects across the Beaufort Sea, the Canadian Arctic Archipelago, and Baffin Bay during late summer 2005, early fall 2006 and fall 2007. Phytoplankton production and chlorophyll a (chl a) biomass were measured at 7 optical depths, including the depth of subsurface chl a maximum $\left(Z_{\mathrm{SCM}}\right)$. Phytoplankton taxonomy, abundance, and size structure were determined at the $\mathrm{Z}_{\mathrm{SCM}}$. Redundancy analyses and non-metric multidimensional scaling were used to assess relationships between phytoplankton composition in relation to biological and environmental variables. In late summer/fall, the CHA was characterized by (1) an oligotrophic flagellate-based system extending over the eastern Beaufort Sea, the peripheral Amundsen Gulf, and the central region of the Canadian Arctic Archipelago; and (2) a eutrophic diatom-based system located in Baffin Bay, Lancaster Sound, and in a hotspot in the central Amundsen Gulf. The oligotrophic regions were characterized by low production and biomass of large phytoplankton cells $(>5 \mu \mathrm{m})$ and relatively high abundance of eukaryotic picophytoplankton $(<2 \mu \mathrm{m})$ and unidentified nanoflagellates $(2-20 \mu \mathrm{m})$. The eutrophic regions were characterized by high production and biomass of large cells and relatively high abundance of centric diatoms, mainly Chaetoceros spp. The distinction between the 2 regimes was explained by differences in stratification (density gradient) and nitrate concentrations at the $\mathrm{Z}_{\mathrm{SCM}}$. This study demonstrates the key role of vertical mixing and nutrient input in shaping the structure and function of phytoplankton communities in the CHA, showing how ongoing environmental changes have the capacity to alter the diversity of biogeographic regions in the CHA.
\end{abstract}

KEY WORDS: Primary production · Phytoplankton communities · Biogeographic regions · Sea ice cover $\cdot$ Stratification $\cdot$ Nutrients $\cdot$ Climate change $\cdot$ Canadian High Arctic

\section{INTRODUCTION}

Polar regions are currently affected by multiple environmental changes exposing marine and terrestrial ecosystems to high environmental pressure and potential regime shifts (e.g. ACIA 2005, Grebmeier et al. 2006, IPCC 2007, Occhipinti-Ambrogi 2007, Barber et al. 2008, Wassmann et al. 2011). The rapid decline of the sea ice cover in the Northern Hemisphere (Stroeve et al. 2007, Comiso et al. 2008, Kwok 
et al. 2009) has led to predictions of a sea ice free summer Arctic by the year 2037 (Wang \& Overland 2009). Sea ice melt also contributes to significant freshwater input (Peterson et al. 2006, McPhee et al. 2009) which, combined with increased precipitation and an intensification of the hydrological cycle (Peterson et al. 2002, Serreze et al. 2006), increases the stratification of the water column (Behrenfeld et al. 2006, Yamamoto-Kawai et al. 2009). In addition, the timing of sea ice formation and melt affects light availability (ACIA 2005) and the duration of the phytoplankton growing season (Arrigo et al. 2008, Kahru et al. 2011). Other Arctic changes include significant warming of the Arctic Ocean (Polyakov et al. 2005, McLaughlin et al. 2009), changes in water mass characteristics and distribution (Shimada et al. 2006, Dmitrenko et al. 2008), and an increase in the frequency and intensity of storms that could induce more episodic vertical mixing events (McCabe et al. 2001, Zhang et al. 2004, Yang 2009).

The balance between stratification, mixing, and the light regime is implicitly linked to the sea ice cover and requires special attention with respect to its influence on phytoplankton production in the Arctic Ocean. Rysgaard et al. (1999) suggested that annual primary production was correlated to the length of the growth season in the Arctic. With in situ experiments, Glud et al. (2007) later showed that short-term rates of primary production were light limited during spring. Recently, Tremblay \& Gagnon (2009) showed that major changes in annual primary production across the Arctic are controlled by dissolved nitrogen supply rather than light availability. In line with fundamental ecological phytoplankton models (Margalef et al. 1979, Legendre \& Rassoulzadegan 1995, Cullen et al. 2002), vertical stratification has been highlighted as a key controlling factor of the productivity and structure of marine ecosystems of the Arctic Ocean (Carmack \& Wassmann 2006, Carmack 2007). Vertical mixing determines, in part, the productivity regime and phytoplankton size structure (i.e. flagellate-based versus diatom-based systems), by favoring possible nutrient replenishment in the upper water column. Flagellate-based systems are typically supported by autochthonous (regenerated) nutrients, and are mainly characterized by picophytoplankton $(<2 \mu \mathrm{m})$, heterotrophic bacteria, and heterotrophic nanoflagellates (Azam et al. 1983, Landry et al. 1997). In contrast, diatom-based systems are composed of large phytoplankton cells, taking up allochthonous (new) nutrients replenished by physical forcing events (Cushing 1989). Both of these phytoplankton regimes are pre- sent in the Arctic Ocean and adjacent seas (e.g. flagellate-based system: Legendre et al. 1993, Booth \& Horner 1997, Li et al. 2009, Tremblay et al. 2009; diatom-based systems: Mostajir et al. 2001, Booth et al. 2002, Hill et al. 2005). However, their large-scale distribution and associated physical forcing remain to be confirmed by multi-year investigations.

Ongoing responses of primary production to climate change in the world's oceans are currently a subject of controversy (e.g. Boyce et al. 2010, 2011, Steinacher et al. 2010, Behrenfeld 2011, Chavez et al. 2011, Taucher \& Oschlies 2011). On the one hand, recent remote sensing studies have suggested a global decrease in oceanic phytoplankton biomass over the past century (Boyce et al. 2010, 2011) and an expansion of oligotrophic areas in the world's oceans (Polovina et al. 2008). In addition, 4 global coupled carbon cycle-climate models are projecting a decrease in global net primary production by 2100 relative to preindustrial conditions, mainly explained by reduced nutrient inputs into the euphotic zone due to enhanced stratification (Steinacher et al. 2010). On the other hand, using satellite and in situ measurements at time series stations, Chavez et al. (2011) found that global marine primary production increased over the past several decades in association with multi-decadal variations. A recent study by Taucher \& Oschlies (2011) suggested that a better understanding and modeling of direct temperature effects on biological processes is required in order to predict the direction of marine primary production changes under global warming. Accordingly, Behrenfeld (2011) suggested that the warming of the upper water column may stimulate plankton metabolism, enhancing photosynthesis, and could contribute to increase global ocean productivity. In contrast to the other oceans, large-scale and long-term observations of phytoplankton production and biomass in the Arctic Ocean are not available in the literature. In this ocean, there is disagreement among fully coupled atmosphere-ocean general circulation models on the long-term trends in net primary production. For example, 3 global coupled carbon cycle-climate models predict an increase in net primary production, while 1 model projects a decrease over the 21st century (Steinacher et al. 2010). Arrigo \& van Dijken (2011) estimated a significant $20 \%$ increase in phytoplankton production in the Arctic Ocean between 1998 and 2009 (range $=441$ to $585 \mathrm{Tg} \mathrm{C} \mathrm{yr}^{-1}$ ), due mainly to secular increases in both the extent of open water $(+27 \%)$ and the duration of the open water season (+45 d). Recently, an increase in stratification associated with a warmer and fresher surface layer 
has been observed in the Canada Basin (YamamotoKawai et al. 2009, McLaughlin \& Carmack 2010), favoring the development of small phytoplankton cells ( $\mathrm{Li}$ et al. 2009). These changes appear to be related to a recent decrease in $\mathrm{CO}_{2}$ uptake capacity (Cai et al. 2010). In a rapidly changing Arctic and with our degree of uncertainty about the directions of present and future primary production changes, it appears essential to understand and predict how phytoplankton regimes will respond to climate change.

The objectives of the present study were to (1) characterize marine phytoplankton regimes in the Canadian High Arctic in terms of phytoplankton production, biomass, cell-size structure, and community composition, and (2) assess the influence of biological and environmental factors on the structure and function of Arctic phytoplankton communities in the context of current environmental changes. We addressed these objectives through a multi-year study covering 3 distinct biogeographic regions. In the west, the Beaufort Sea is characterized by nutrientpoor surface waters and low primary production due to the strong vertical stratification caused by freshwater input from the Mackenzie River and sea ice meltwater (Carmack \& Macdonald 2002). In the east, the North Water Polynya in Baffin Bay is considered the most productive region in the Canadian Arctic due to enhanced vertical mixing (Klein et al. 2002, Tremblay et al. 2002). Baffin Bay and the Beaufort Sea are connected by the narrow channels and interconnected sounds of the Canadian Arctic Archipelago, which form a complex and diverse shelf environment (Michel et al. 2006, Carmack \& McLaughlin 2011). A spatial gradient in phytoplankton size structure has been previously observed in this region, with a transition from picophytoplankton in the west to nanophytoplankton in the east (Tremblay et al. 2009). Here, we aimed at moving further ahead by evaluating the structure and function of the entire size spectrum of phytoplankton communities in relation to water column properties.

\section{MATERIALS AND METHODS}

\section{Study area and sampling design}

Sampling was performed onboard the CCGS 'Amundsen' along recurrent transects from the Beaufort Sea to Baffin Bay from 16 August to 13 September 2005, 7 September to 17 October 2006, and 29 September to 5 November 2007 (Fig. 1). A total of 18,
25 , and 31 stations were visited in 2005, 2006, and 2007, respectively; hereafter, these sampling seasons are referred to as late summer 2005, early fall 2006, and fall 2007 (Table 1). Additional measurements of chlorophyll a ( $\mathrm{chl}$ a) concentrations were obtained from 3 ArcticNet expeditions from 9 to 24 September 2008, 12 October to 7 November 2009, and 28 September to 28 October 2010 and were only used to illustrate the relationship between the chl a concentration and sea ice coverage (see Fig. 8). Water depth was deeper than $200 \mathrm{~m}$ at $64 \%, 56 \%$, and $100 \%$ of the stations visited in the Beaufort Sea, Canadian Arctic Archipelago, and Baffin Bay, respectively (Fig. 1).

At each station, sea ice coverage $\left(\mathrm{I}_{\mathrm{C}}\right)$ was estimated from shipboard visual observations, using the standard procedure described by Environment Canada (2005). A vertical profile of irradiance (PAR: photosynthetically active radiation, 400 to $700 \mathrm{~nm}$ ) was then performed with a PNF-300 radiometer (Biospherical Instruments) and used to determine the depth of the euphotic zone $\left(Z_{\text {eu }}, 0.2 \%\right.$ of surface irradiance, as in Tremblay et al. 2009). Downwelling incident PAR was also measured at 10 min intervals from the beginning to the end of each expedition with a LI-COR cosine sensor (LI-190SA) placed on the foredeck in an area protected from shading.

At each station, water samples were collected with a rosette sampler equipped with 121 Niskin-type bottles (OceanTest Equipment, $\mathrm{n}=24$ ), a Sea-Bird 911plus conductivity, temperature, depth (CTD) probe for salinity and temperature measurements, a nitrate sensor (ISUS V2, Satlantic), and a chlorophyll fluorometer (SeaPoint). Water samples were collected at 7 optical depths $(100,50,30,15,5,1$, and $0.2 \%$ of surface irradiance), including the depth of the subsurface maximum chlorophyll fluorescence $\left(\mathrm{Z}_{\mathrm{SCM}}\right)$. Subsamples were transferred into acidwashed bottles and isothermal containers, and processed immediately after collection.

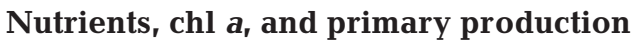

Nutrient and chl a concentrations and primary production rates were determined at the 7 optical depths, including $\mathrm{Z}_{\mathrm{SCM}}$. Nitrate plus nitrite $\left(\mathrm{NO}_{3}+\mathrm{NO}_{2}\right)$, phosphate $\left(\mathrm{PO}_{4}\right)$, and silicic acid $\left(\mathrm{Si}(\mathrm{OH})_{4}\right)$ concentrations were measured immediately after sampling using a Bran-Luebbe 3 autoanalyzer (adapted from Grasshoff et al. 1999). Nitrate data were used to post-calibrate the optical nitrate probe and generate high-resolution vertical profiles, as described by Martin et al. (2010). 


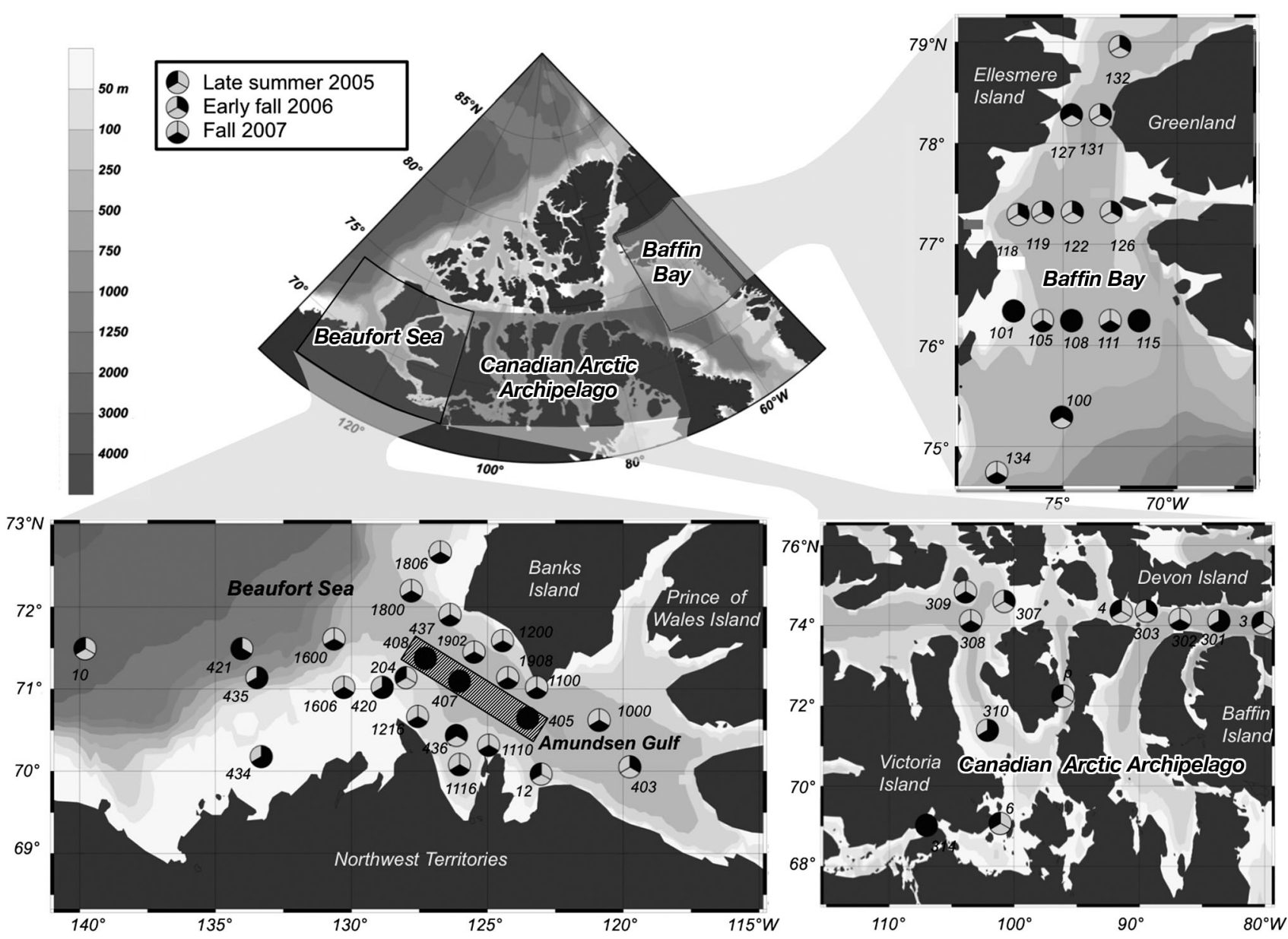

Fig. 1. Location of the sampling stations in the Canadian High Arctic during late summer 2005, early fall 2006, and fall 2007. In the Beaufort Sea map, the box delimits the Amundsen Gulf hotspot stations. Solid circles mean that the station was sampled during the 3 years

Table 1. Environmental variables (mean $\pm \mathrm{SE}$ ) in the 3 biogeographic regions of the Canadian High Arctic during late summer 2005, early fall 2006, and fall 2007. $\mathrm{T}_{\text {eu }}$ : water temperature averaged over the depth of the euphotic zone $\left(\mathrm{Z}_{\text {eu }}\right)_{i} \mathrm{~S}_{\mathrm{eu}}$ : salinity averaged over $Z_{\text {eui }} \Delta \sigma_{t}$ : stratification index; $\mathrm{I}_{\mathrm{C}}$ : percent areal ice cover; $\mathrm{E}_{\mathrm{d}}$ : daily incident irradiance; $\mathrm{Z}_{\mathrm{m}}$ : surface mixed layer depth; $Z_{\mathrm{SCM}}: Z_{\mathrm{Nit}}$ : ratio of maximum chlorophyll fluorescence depth to nitracline depth; $\mathrm{NO}_{3}+\mathrm{NO}_{2}$ : nitrate plus nitrite concentration at $\mathrm{Z}_{\mathrm{SCM}} ; \mathrm{Si}(\mathrm{OH})_{4}$ : silicic acid concentration at $\mathrm{Z}_{\mathrm{SCM}} ; \mathrm{PO}_{4}$ : phosphate concentration at $\mathrm{Z}_{\mathrm{SCM}}$. BS: Beaufort Sea; CA: Canadian Arctic Archipelago; BB: Baffin Bay

\begin{tabular}{|c|c|c|c|c|c|c|c|c|c|c|c|}
\hline $\begin{array}{l}\text { Biogeo } \\
\text { graphic } \\
\text { region }\end{array}$ & $\begin{array}{ll}\text { hic } & \mathrm{T}_{\mathrm{eu}} \\
\mathrm{n} & \left({ }^{\circ} \mathrm{C}\right)\end{array}$ & $\mathrm{S}_{\mathrm{eu}}$ & $\Delta \sigma_{\mathrm{t}}$ & $\begin{array}{l}\mathrm{I}_{\mathrm{C}} \\
(\%)\end{array}$ & $\begin{array}{c}\mathrm{E}_{\mathrm{d}} \\
\left(\mathrm{E} \mathrm{m}^{-2} \mathrm{~d}^{-1}\right)\end{array}$ & $\begin{array}{l}Z_{\mathrm{eu}} \\
(\mathrm{m})\end{array}$ & $\begin{array}{l}Z_{m} \\
(m)\end{array}$ & $\begin{array}{c}Z_{\mathrm{SCM}}: Z_{\mathrm{Nit}} \\
(\mathrm{m}: \mathrm{m})\end{array}$ & $\begin{array}{l}\mathrm{NO}_{3}+\mathrm{NO}_{2} \\
\left(\mu \mathrm{mol} \mathrm{l} \mathrm{l}^{-1}\right)\end{array}$ & $2 \underset{\left.(\mu \mathrm{mol} \mathrm{l})^{-1}\right)}{\mathrm{Si}(\mathrm{OH})_{4}}$ & $\begin{array}{c}\mathrm{PO}_{4} \\
\left(\mu \mathrm{mol} \mathrm{l} \mathrm{l}^{-1}\right)\end{array}$ \\
\hline \multicolumn{12}{|c|}{ Late summer 2005} \\
\hline BS & $0.4 \pm 0.4$ & $29.9 \pm 0.5$ & $5.0 \pm 0.4$ & $23 \pm 6$ & $15.8 \pm 1.5$ & $74.1 \pm 9.5$ & $8.1 \pm 1.3$ & $0.8 \pm 0.1$ & $1.7 \pm 0.7$ & $5.6 \pm 0.8$ & $0.88 \pm 0.09$ \\
\hline CA & $0.6 \pm 0.7$ & $30.2 \pm 1.3$ & $3.8 \pm 0.7$ & $2 \pm 2$ & $12.8 \pm 2.5$ & $35.5 \pm 7.2$ & $8.0 \pm 3.6$ & $1.1 \pm 0.1$ & $3.3 \pm 0.91$ & $10.1 \pm 0.8$ & $1.00 \pm 0.04$ \\
\hline $\mathrm{BB}$ & $0.6 \pm 0.6$ & $32.1 \pm 0.4$ & $1.7 \pm 0.3$ & $14 \pm 15$ & $19.5 \pm 2.1$ & $52.4 \pm 8.1$ & $16.4 \pm 8.9$ & $1.2 \pm 0.5$ & $2.6 \pm 1.4$ & $4.9 \pm 1.3$ & $0.70 \pm 0.09$ \\
\hline \multicolumn{12}{|c|}{ Early fall 2006} \\
\hline $\mathrm{BS}$ & $-0.2 \pm 0.3$ & $30.0 \pm 0.4$ & $3.5 \pm 0.8$ & 0 & $5.8 \pm 1.0$ & $51.6 \pm 5.6$ & $11.9 \pm 1.3$ & $0.8 \pm 0.1$ & $2.4 \pm 0.7$ & $8.0 \pm 1.5$ & $0.91 \pm 0.11$ \\
\hline CA & $0.0 \pm 0.4$ & $29.2 \pm 1.0$ & $3.1 \pm 0.7$ & $10 \pm 6$ & $9.9 \pm 1.7$ & $49.0 \pm 6.8$ & $10.0 \pm 3.1$ & $1.0 \pm 0.4$ & $2.3 \pm 1.3$ & $6.1 \pm 2.4$ & $0.92 \pm 0.13$ \\
\hline $\mathrm{BB}$ & $-0.3 \pm 0.3$ & $31.9 \pm 0.3$ & $1.0 \pm 0.2$ & $8 \pm 3$ & $10.2 \pm 1.4$ & $47.1 \pm 2.8$ & $22.4 \pm 6.2$ & $1.3 \pm 0.2$ & $3.2 \pm 0.5$ & $4.6 \pm 0.7$ & $0.65 \pm 0.05$ \\
\hline \multicolumn{12}{|c|}{ Fall 2007} \\
\hline BS & $-1.2 \pm 0.1$ & $31.6 \pm 0.3$ & $1.3 \pm 0.5$ & $41 \pm 9$ & $1.0 \pm 0.2$ & $60.0 \pm 5.7$ & $19.6 \pm 2.6$ & $0.5 \pm 0.1$ & $5.3 \pm 1.5$ & $10.8 \pm 2.3$ & $1.04 \pm 0.08$ \\
\hline $\mathrm{CA}$ & $-0.8 \pm 0.3$ & $30.4 \pm 0.7$ & $2.3 \pm 0.4$ & $48 \pm 14$ & $3.3 \pm 0.8$ & $51.5 \pm 6.9$ & $19.0 \pm 4.0$ & $0.3 \pm 0.1$ & $0.39 \pm 0.04$ & $42.1 \pm 0.3$ & $0.67 \pm 0.03$ \\
\hline BB & $-0.9 \pm 0.2$ & $32.1 \pm 0.5$ & $1.2 \pm 0.2$ & $28 \pm 12$ & 5.0 & $69.3 \pm 9.6$ & $18.2 \pm 3.9$ & $1.2 \pm 0.3$ & $2.2 \pm 0.3$ & $4.0 \pm 0.7$ & $0.76 \pm 0.05$ \\
\hline
\end{tabular}


Duplicate subsamples (500 ml) for chl a determination were filtered onto Whatman GF/F glass-fiber filters (referred to as total phytoplankton biomass: $\mathrm{B}_{\mathrm{T}}$, $\geq 0.7 \mu \mathrm{m}$ ) and onto $5 \mu \mathrm{m}$ Nuclepore polycarbonate membrane filters (referred to as biomass of large phytoplankton cells: $\left.\mathrm{B}_{\mathrm{L},} \geq 5 \mu \mathrm{m}\right)$. Chl a concentrations were measured using a Turner Designs 10-AU fluorometer, following a $24 \mathrm{~h}$ extraction in $90 \%$ acetone at $4^{\circ} \mathrm{C}$ in the dark without grinding (acidification method: Parsons et al. 1984).

At selected stations, primary production was estimated using the ${ }^{14} \mathrm{C}$-uptake method (Knap et al. 1996, Gosselin et al. 1997). Two light and 1 dark $500 \mathrm{ml}$ Nalgene polycarbonate bottles were filled with seawater from each light level and inoculated with $20 \mu \mathrm{Ci}$ of $\mathrm{NaH}^{14} \mathrm{CO}_{3}$. The dark bottle contained $0.5 \mathrm{ml}$ of $0.02 \mathrm{M}$ 3-(3,4-dichlorophenyl)-1,1-dimethyl urea (DCMU; Legendre et al. 1983). Bottles containing ${ }^{14} \mathrm{C}$ were incubated for $24 \mathrm{~h}$, generally starting in the morning (Mingelbier et al. 1994), under simulated in situ conditions in a deck incubator with running surface seawater (see Garneau et al. 2007 for details). At the end of the incubation period, $250 \mathrm{ml}$ were filtered onto Whatman GF/F glass-fiber filters (referred to as total particulate phytoplankton production: $\mathrm{P}_{\mathrm{T}}, \geq 0.7 \mu \mathrm{m}$ ), and the remaining $250 \mathrm{ml}$ were filtered onto $5 \mu \mathrm{m}$ Nuclepore polycarbonate membrane filters (referred to as production of large phytoplankton cells: $\left.\mathrm{P}_{\mathrm{L}}, \geq 5 \mu \mathrm{m}\right)$. Each filter was then placed in a borosilicate scintillation vial, acidified with $0.2 \mathrm{ml}$ of $0.5 \mathrm{~N} \mathrm{HCl}$, and left to evaporate overnight under the fume hood to remove any ${ }^{14} \mathrm{C}$ that had not been incorporated (Lean \& Burnison 1979). After this period, $10 \mathrm{ml}$ of Ecolume (ICN) scintillation cocktail were added to each vial. The activity of each sample was determined using a Packard Tri-Carb 2900 TR liquid scintillation counter.

\section{Cell abundances}

Samples for the identification and enumeration of protists $>2 \mu \mathrm{m}$ at $\mathrm{Z}_{\mathrm{SCM}}$ were preserved in acidic Lugol's solution (final concentration of $0.4 \%$, Parsons et al. 1984) and stored in the dark at $4^{\circ} \mathrm{C}$ until analysis. Cell identification was carried out at the lowest possible taxonomic rank using an inverted microscope (Wild Herbrugg) in accordance with Lund et al. (1958). A minimum of 400 cells (accuracy: $\pm 10 \%$ ) and 3 transects were counted at a magnification of $200 \times$ and $400 \times$. The main taxonomic references used to identify the phytoplankton were Tomas (1997) and Bérard-Therriault et al. (1999).
Pico- $(<2 \mu \mathrm{m})$ and nanophytoplankton $(2-20 \mu \mathrm{m})$ cell abundances were determined at each station at $\mathrm{Z}_{\mathrm{SCM}}$. Subsamples were fixed with glutaraldehyde Grade I (Sigma) to a final concentration of $0.1 \%$, stored in liquid nitrogen onboard the ship, and kept frozen at $-80^{\circ} \mathrm{C}$ before analysis (Marie et al. 2005). Subsamples were pre-screened on a $40 \mu \mathrm{m}$ nylon cell strainer (Tremblay et al. 2009). Cells were counted using an EPICS ALTRA flow cytometer (Beckman Coulter) equipped with a $488 \mathrm{~nm}$ laser (15 mW output). Microspheres (1 $\mathrm{mm}$, Fluoresbrite plain YG, Polysciences) were added to each sample as an internal standard. Picocyanobacteria and photosynthetic eukaryotes were distinguished by their differences in orange fluorescence from phycoerythrin $(575 \pm 20 \mathrm{~nm})$ and red fluorescence from chlorophyll $(675 \pm 10 \mathrm{~nm})$. Pico- and nanophytoplankton, counted by flow cytometry, were discriminated based on forward scatter calibration with known-size microspheres. Microplankton (>20 $\mu \mathrm{m}$ ) abundances were determined from microscopic counts.

\section{Calculations and statistical analyses}

Daily incident downwelling irradiance $\left(E_{D}\right)$ was calculated at each station. Water temperature and salinity were averaged over the euphotic zone and will hereafter be referred to as $T_{\text {eu }}$ and $S_{\text {eur }}$ respectively. The surface mixed layer $\left(Z_{m}\right)$ was defined as the depth where the gradient in density (sigma- $t, \sigma_{t}$ ) is $>0.03 \mathrm{~m}^{-1}$, in accordance with Tremblay et al. (2009). The nitracline $\left(Z_{N i t}\right)$ was determined from the second derivative of the nitrate concentration estimated with the Satlantic sensor with respect to depth according to Martinson \& Iannuzzi (1998). The stratification index of the upper water column $\left(\Delta \sigma_{t}\right)$ was estimated as the difference in $\sigma_{t}$ values between 80 and $5 \mathrm{~m}$, as in Tremblay et al. (2009). Nutrient concentrations were determined for $Z_{\mathrm{SCM}}$ and were integrated over $Z_{m}$ and $Z_{\text {eu }}$ using trapezoidal integration (Knap et al. 1996). Small cell phytoplankton production $\left(\mathrm{P}_{\mathrm{S}}, 0.7-5 \mu \mathrm{m}\right)$ and biomass $\left(\mathrm{B}_{\mathrm{S}}, 0.7-5 \mu \mathrm{m}\right)$ were calculated by subtracting $\mathrm{P}_{\mathrm{L}}$ from $\mathrm{P}_{\mathrm{T}}$ and $\mathrm{B}_{\mathrm{L}}$ from $\mathrm{B}_{\mathrm{T}}$, respectively. Chl a concentration and primary production values of the 2 size fractions were also integrated over $\mathrm{Z}_{\mathrm{eu}}$.

Prior to statistical analyses, all environmental and biological variables were tested for homoscedasticity and normality of distribution, using residual diagrams and a Shapiro-Wilk test, respectively. When required, a logarithmic or square-root transformation 
was applied to the data. For each variable, 2-way analysis of variance (ANOVA) was performed to assess significant differences between sampling years (i.e. 2005, 2006, and 2007) and biogeographic regions (i.e. Beaufort Sea, Canadian Arctic Archipelago, and Baffin Bay) (Sokal \& Rohlf 1995). The ANOVA test was completed by a post hoc test (Tukey's HSD test for unequal sample sizes). Spearman's rank correlation $\left(\mathrm{r}_{\mathrm{s}}\right)$ was computed to infer relationships between 2 variables (Sokal \& Rohlf 1995). Model II linear regressions (reduced major axis; Sokal \& Rohlf 1995) were used to evaluate linear relationships between phytoplankton chl a biomass and sea ice coverage in contrasting regions. These statistical tests were carried out using JMP version 7.01 software.

A non-metric multidimensional scaling (MDS) ordination of a Bray-Curtis similarity matrix coupled with a group-average cluster analysis was performed to characterize groups of stations with similar taxonomic composition (Clarke \& Warwick 2001), using PRIMER v6 software (Clarke \& Gorley 2006). Taxonomic groups (i.e. chlorophytes, choanoflagellates, dictyochophytes, euglenids, raphidophytes, and ciliates) making up, on average, $<2 \%$ of total protist abundance (determined from light microscopy) were excluded from the analysis in order to reduce double zeros in the data matrix. The relative abundance of the remaining taxonomic groups (i.e. centric diatoms, pennate diatoms, dinoflagellates, chrysophytes, cryptophytes, prasinophytes, prymnesiophytes, and unidentified flagellates) was used to calculate the similarity matrix.

An analysis of similarities (1-way ANOSIM) was performed on the Bray-Curtis similarity matrix to identify groups of stations with significantly different taxonomic composition (Clarke \& Warwick 2001). A breakdown of species similarities (SIMPER) was performed to determine which taxonomic entry combination led to the resulting groups (Clarke 1993).

A redundancy analysis (RDA) was conducted to assess interactions between major taxonomic groups of protists and biological and environmental variables. Linear-based ordination was selected based on gradient lengths (expressed in standard deviation units) of the first axis being $<2$. After testing several transformations (i.e. Chord, $\chi^{2}$, and Hellinger), Legendre \& Gallagher (2001) concluded that in the case of linear-based ordination, Hellinger transformation provided the best results. The direct gradient technique of RDA was performed using forward selection (and a Monte-Carlo permutation test, $\mathrm{n}=$ 9999 permutations) to determine a subset of significant environmental and biological variables explaining individual variation of taxonomic groups. Intraset Pearson's correlation $\left(\mathrm{r}_{\mathrm{P}}\right)$ between environmental variables was determined by RDAs. Two ordination diagrams were produced to visualize interactions between various taxonomic groups of protists in relation to (1) biological and (2) environmental variables. RDA was carried out using the CANOCO v4.5 software package (ter Braak \& Šmilauer 2002).

Table 2. Biological variables (mean \pm SE) in the 3 oceanographic regions of the Canadian High Arctic during late summer 2005, early fall 2006, and fall 2007. $\mathrm{P}_{\mathrm{T}}$ : total phytoplankton production; $\mathrm{P}_{\mathrm{S}}$ : production of small phytoplankton $(0.7-5 \mu \mathrm{m}) ; \mathrm{P}_{\mathrm{L}}$ : production of large phytoplankton $(\geq 5 \mu \mathrm{m}) ; \mathrm{B}_{\mathrm{T}}$ : total phytoplankton biomass; $\mathrm{B}_{\mathrm{S}}$ : biomass of small phytoplankton $(0.7-5 \mu \mathrm{m})$; $\mathrm{B}_{\mathrm{L}}$ : biomass of large phytoplankton $(\geq 5 \mu \mathrm{m})$; Diat.: diatoms; Flag.: flagellates; Dino.: dinoflagellates; Others: other protists $>2 \mu \mathrm{m}$, including ciliates, choanoflagellates, and unidentified cells; Pico.: picophytoplankton $(<2 \mu \mathrm{m})$ percent abundance; Nano.: nanophytoplankton $(2-20 \mu \mathrm{m})$ percent abundance; Micro.: microplankton $(\geq 20 \mu \mathrm{m})$ percent abundance. BS: Beaufort Sea; CA: Canadian Arctic Archipelago; BB: Baffin Bay; nd: no data available. Phytoplankton production and biomass were integrated over the euphotic zone. Community structure and composition were measured at the depth of the subsurface chlorophyll a maximum $\left(\mathrm{Z}_{\mathrm{SCM}}\right)$

\begin{tabular}{|c|c|c|c|c|c|c|c|c|c|c|c|c|c|}
\hline $\begin{array}{l}\text { Biogeo } \\
\text { graphi } \\
\text { region }\end{array}$ & \multicolumn{3}{|c|}{ Production $\left(\mathrm{mg} \mathrm{C} \mathrm{m}^{-2} \mathrm{~d}^{-1}\right)$} & \multicolumn{3}{|c|}{ Biomass (mg chl a m²) } & \multicolumn{4}{|c|}{ Community composition (\%) } & \multicolumn{3}{|c|}{ Community structure (\%) } \\
\hline \multicolumn{14}{|c|}{ Late summer 2005} \\
\hline $\mathrm{CA}$ & $295 \pm 149$ & $172 \pm 52$ & $123 \pm 101$ & $38.3 \pm 15.7$ & $16.8 \pm 4.7$ & $21.5 \pm 12.0$ & $29.8 \pm 17.7$ & $49.4 \pm 11.8$ & $1.7 \pm 0.4$ & $19.0 \pm 9.1$ & $67.9 \pm 13.7$ & $30.6 \pm 13.4$ & $41.5 \pm 0.9$ \\
\hline $\mathrm{BB}$ & $448 \pm 153$ & $314 \pm 133$ & $134 \pm 31$ & $56.8 \pm 17.8$ & $26.5 \pm 10.4$ & $30.4 \pm 15.7$ & $25.2 \pm 14.3$ & $64.6 \pm 14.5$ & $3.3 \pm 1.2$ & $6.9 \pm 2.5$ & $66.6 \pm 10.6$ & $32.6 \pm 10.0$ & $0.8 \pm 0.6$ \\
\hline \multicolumn{14}{|c|}{ Early fall 2006} \\
\hline BB & $310 \pm 93$ & $158 \pm 54$ & $152 \pm 47$ & $71.4 \pm 10.7$ & $18.1 \pm 3.5$ & $53.3 \pm 7.7$ & $65.9 \pm 5.9$ & $25.6 \pm 3.7$ & $3.4 \pm 1.1$ & $5.1 \pm 1.8$ & $34.5 \pm 10.0$ & $50.4 \pm 9.9$ & $15.1 \pm 3.8$ \\
\hline \multicolumn{14}{|c|}{ Fall 2007} \\
\hline BS & nd & nd & nd & $17.7 \pm 3.0$ & $8.3 \pm 1.4$ & $8.7 \pm 2.4$ & $10.2 \pm 6.4$ & $75.2 \pm 5.3$ & $8.0 \pm 1.5$ & $6.6 \pm 1.0$ & $70.3 \pm 5.4$ & $28.1 \pm 5.3$ & $1.6 \pm 0.2$ \\
\hline CA & $49 \pm 12$ & $42 \pm 9$ & $7.6 \pm 3$ & $12.4 \pm 1.0$ & $9.9 \pm 0.5$ & $2.5 \pm 0.6$ & $3.4 \pm 1.0$ & $82.0 \pm 2.6$ & $9.2 \pm 1.3$ & $5.4 \pm 0.6$ & $88.1 \pm 2$ & $11.5 \pm 1.8$ & $0.4 \pm 0.3$ \\
\hline BB & $326 \pm 137$ & $148 \pm 62$ & $178 \pm 77$ & $62.4 \pm 20.1$ & $19.8 \pm 7.9$ & $42.6 \pm 16.1$ & $44.8 \pm 10.9$ & $40.7 \pm 8.3$ & $9.1 \pm 3.5$ & $5.5 \pm 0.7$ & $51.3 \pm 11.6$ & $36.5 \pm 8.2$ & $12.2 \pm 5.9$ \\
\hline
\end{tabular}


Table 3. Summary of 2-way analysis of variance (ANOVA) and Tukey test for environmental and biological variables in the 3 biogeographic regions of the Canadian High Arctic during late summer 2005, early fall 2006, and fall 2007. Total abund.: total abundance of protists $>2 \mu \mathrm{m}$ at the depth of the subsurface chlorophyll a maximum $\left(\mathrm{Z}_{\mathrm{SCM}}\right)$. Other abbreviations are defined in Tables 1 \& 2. ns: not significant. For post hoc Tukey tests: $\mathrm{A}>\mathrm{B}>\mathrm{C}$

\begin{tabular}{|c|c|c|c|c|c|c|c|c|c|}
\hline & \multicolumn{3}{|c|}{ — Two-way ANOVA- } & \multirow[b]{2}{*}{ BS } & \multicolumn{3}{|c|}{-Tukey test $(\alpha \leq 0.05$} & \multirow{2}{*}{$\begin{array}{l}\text { Early fall } \\
2006\end{array}$} & \multirow[b]{2}{*}{$\begin{array}{c}\text { Fall } \\
2007\end{array}$} \\
\hline & Region & Season & $\begin{array}{c}\text { Region } \times \\
\text { Season }\end{array}$ & & $\mathrm{CA}$ & $\mathrm{BB}$ & $\begin{array}{l}\text { Late summer } \\
2005\end{array}$ & & \\
\hline \multicolumn{10}{|l|}{ Environmental variable } \\
\hline $\mathrm{T}_{\mathrm{eu}}\left({ }^{\circ} \mathrm{C}\right)$ & ns & $<0.001$ & ns & & & & A & A & $\mathrm{B}$ \\
\hline $\mathrm{S}_{\mathrm{eu}}$ & $<0.001$ & ns & ns & $\mathrm{B}$ & B & $\mathrm{A}$ & & & \\
\hline$\Delta \sigma_{\mathrm{t}}$ & $<0.001$ & $<0.001$ & ns & $\mathrm{A}$ & $\mathrm{A}, \mathrm{B}$ & B & A & $\mathrm{A}, \mathrm{B}$ & B \\
\hline$I_{C}(\%)$ & ns & $<0.01$ & ns & & & & $\mathrm{B}$ & $\mathrm{B}$ & $\mathrm{A}$ \\
\hline$E_{d}\left(E m^{-2} d^{-1}\right)$ & $<0.01$ & $<0.001$ & ns & A & $\mathrm{A}, \mathrm{B}$ & A & A & $\mathrm{B}$ & $\mathrm{C}$ \\
\hline $\mathrm{Z}_{\mathrm{eu}}(\mathrm{m})$ & ns & ns & ns & & & & & & \\
\hline $\mathrm{Z}_{\mathrm{m}}(\mathrm{m})$ & ns & $<0.01$ & ns & & & & $\mathrm{B}$ & $\mathrm{A}, \mathrm{B}$ & $\mathrm{A}$ \\
\hline $\mathrm{Z}_{\mathrm{SCM}}: \mathrm{Z}_{\mathrm{Nit}}(\mathrm{m}: \mathrm{m})$ & $<0.001$ & ns & ns & B & B & A & & & \\
\hline $\mathrm{NO}_{3}+\mathrm{NO}_{2}$ at $\mathrm{Z}_{\mathrm{SCM}}\left(\mu \mathrm{mol} \mathrm{l} \mathrm{l}^{-1}\right)$ & ns & ns & & & & & & & \\
\hline $\mathrm{Si}(\mathrm{OH})_{4}$ at $\mathrm{Z}_{\mathrm{SCM}}\left(\mu \mathrm{mol} \mathrm{l^{-1 }}\right)$ & $<0.01$ & ns & & A & $\mathrm{A}, \mathrm{B}$ & $\mathrm{B}$ & & & \\
\hline $\mathrm{PO}_{4}$ at $\mathrm{Z}_{\mathrm{SCM}}\left(\mu \mathrm{mol} \mathrm{l^{-1 }}\right)$ & $<0.01$ & ns & & $\mathrm{A}$ & $\mathrm{A}, \mathrm{B}$ & $\mathrm{B}$ & & & \\
\hline$\left(\mathrm{NO}_{3}+\mathrm{NO}_{2}\right): \mathrm{PO}_{4}(\mathrm{~mol}: \mathrm{mol})$ & ns & ns & ns & & & & & & \\
\hline$\left(\mathrm{NO}_{3}+\mathrm{NO}_{2}\right): \mathrm{Si}(\mathrm{OH})_{4}(\mathrm{~mol}: \mathrm{mol})$ & $<0.01$ & ns & ns & B & B & A & & & \\
\hline \multicolumn{10}{|l|}{ Biological variable } \\
\hline $\mathrm{P}_{\mathrm{T}}\left(\mathrm{mg} \mathrm{C} \mathrm{m}^{-2} \mathrm{~d}^{-1}\right)$ & $<0.01$ & ns & $\mathrm{ns}$ & $\mathrm{B}$ & $\mathrm{A}, \mathrm{B}$ & $\mathrm{A}$ & & & \\
\hline 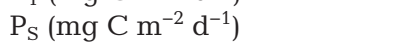 & $<0.01$ & $<0.01$ & ns & $\mathrm{B}$ & $\mathrm{A}, \mathrm{B}$ & $\mathrm{A}$ & A & $\mathrm{B}$ & \\
\hline 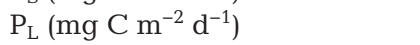 & $<0.01$ & ns & ns & $\mathrm{B}$ & $\mathrm{A}, \mathrm{B}$ & $\mathrm{A}$ & & & \\
\hline $\mathrm{B}_{\mathrm{T}}\left(\mathrm{mg} \operatorname{chl} a \mathrm{~m}^{-2}\right)$ & $<0.001$ & ns & ns & B & B & A & & & \\
\hline $\mathrm{B}_{\mathrm{S}}\left(\mathrm{mg} \mathrm{chl} a \mathrm{~m}^{-2}\right)$ & ns & ns & ns & & & & & & \\
\hline $\mathrm{B}_{\mathrm{L}}\left(\mathrm{mg} \mathrm{chl} a \mathrm{~m}^{-2}\right)$ & $<0.001$ & ns & ns & B & B & A & & & \\
\hline Diat. (\%) & $<0.001$ & $<0.001$ & ns & $\mathrm{B}$ & $\mathrm{A}, \mathrm{B}$ & $\mathrm{A}$ & $\mathrm{B}$ & $\mathrm{A}$ & $\mathrm{B}$ \\
\hline Flag. (\%) & $<0.01$ & $<0.001$ & ns & $\mathrm{A}$ & $\mathrm{A}, \mathrm{B}$ & $\mathrm{B}$ & A & $\mathrm{B}$ & $\mathrm{A}$ \\
\hline Dino. (\%) & ns & $<0.001$ & ns & & & & $\mathrm{B}$ & B & $\mathrm{A}$ \\
\hline Others $(\%)$ & ns & 0.05 & ns & & & & $\mathrm{A}$ & B & $\mathrm{A}, \mathrm{B}$ \\
\hline Pico. (\%) & $<0.01$ & $<0.001$ & ns & $\mathrm{A}$ & A & $\mathrm{B}$ & A & B & A \\
\hline Nano. (\%) & ns & $<0.01$ & ns & $\mathrm{A}$ & $\mathrm{A}$ & A & $\mathrm{A}, \mathrm{B}$ & $\mathrm{A}$ & $\mathrm{B}$ \\
\hline Micro. (\%) & $<0.001$ & $<0.001$ & ns & $\mathrm{B}$ & $\mathrm{B}$ & $\mathrm{A}$ & B & A & $\mathrm{A}, \mathrm{B}$ \\
\hline Total abund. $\left(10^{6}\right.$ cells $\left.1^{-1}\right)$ & $<0.01$ & $<0.001$ & ns & $\mathrm{B}$ & $\mathrm{B}$ & A & $\mathrm{A}$ & $\mathrm{A}, \mathrm{B}$ & B \\
\hline
\end{tabular}

\section{RESULTS}

\section{Spatio-temporal variability of environmental factors in the Canadian High Arctic}

The environmental and biological variables measured in the 3 biogeographic regions of the Canadian High Arctic (i.e. Beaufort Sea, Canadian Arctic Archipelago, and Baffin Bay) during late summer 2005, early fall 2006, and fall 2007 are summarized in Tables 1 \& 2. Two-way ANOVAs revealed significant regional and seasonal differences in the study area (Table 3). During the 3 sampling periods, salinity averaged over the $Z_{\mathrm{eu}}\left(\mathrm{S}_{\mathrm{eu}}\right), \mathrm{Z}_{\mathrm{SCM}}: Z_{\mathrm{Nit}}$ ratio, and $\left(\mathrm{NO}_{3}+\mathrm{NO}_{2}\right): \mathrm{Si}(\mathrm{OH})_{4}$ molar ratio at $\mathrm{Z}_{\mathrm{SCM}}$ were significantly higher in Baffin Bay than in the other 2 biogeographic regions (Fig. 2b,d,e, Tables 1 \& 3). $\mathrm{Z}_{\mathrm{SCM}}$ was $<Z_{\text {Nit }}$ in the Beaufort Sea and $\geq Z_{\text {Nit }}$ in Baffin Bay.
$Z_{\text {SCM }}$ was $\geq Z_{\text {Nit }}$ in 2005 and 2006, and $<Z_{\text {Nit }}$ in 2007 in the Canadian Arctic Archipelago (Fig. 2e).

The $\left(\mathrm{NO}_{3}+\mathrm{NO}_{2}\right): \mathrm{Si}(\mathrm{OH})_{4}$ and $\left(\mathrm{NO}_{3}+\mathrm{NO}_{2}\right): \mathrm{PO}_{4}$ molar ratios at $Z_{\mathrm{SCM}}$ were generally lower than the Redfield-Brzezinski values (1 and 16, respectively; Redfield et al. 1963, Brzezinski 1985, Conley \& Malone 1992). Yet, the $\left(\mathrm{NO}_{3}+\mathrm{NO}_{2}\right): \mathrm{Si}(\mathrm{OH})_{4}$ molar ratio was $>1$ at $18 \%$ of the stations visited in Baffin Bay in early fall 2006, suggesting a possible shortage in $\mathrm{Si}(\mathrm{OH})_{4}$ at $\mathrm{Z}_{\mathrm{SCM}}$. For each nutrient $\left(\mathrm{NO}_{3}+\mathrm{NO}_{2}\right.$, $\mathrm{Si}(\mathrm{OH})_{4}$, and $\left.\mathrm{PO}_{4}\right)$, concentrations at $\mathrm{Z}_{\mathrm{SCM}}$ were positively correlated with nutrient concentrations at $\mathrm{Z}_{\mathrm{m}}$ and $\mathrm{Z}_{\mathrm{eu}}$ (for $\mathrm{NO}_{3}+\mathrm{NO}_{2}: \mathrm{r}_{\mathrm{s}}=0.24$ and $0.34, \mathrm{p}<0.05$; for $\mathrm{Si}(\mathrm{OH})_{4}: \mathrm{r}_{\mathrm{s}}=0.57$ and $0.43, \mathrm{p}<0.001 ;$ for $\mathrm{PO}_{4}: \mathrm{r}_{\mathrm{s}}=0.63$ and $0.36, \mathrm{p}<0.05)$. The western part of the transect $\left(>95^{\circ} \mathrm{W}\right.$, Fig. 1) was characterized by higher $\mathrm{Si}(\mathrm{OH})_{4}$ and $\mathrm{PO}_{4}$ concentrations at $\mathrm{Z}_{\mathrm{SCM}}$ than the eastern part (Table 3). $\mathrm{NO}_{3}+\mathrm{NO}_{2}$ concentrations did not show any 

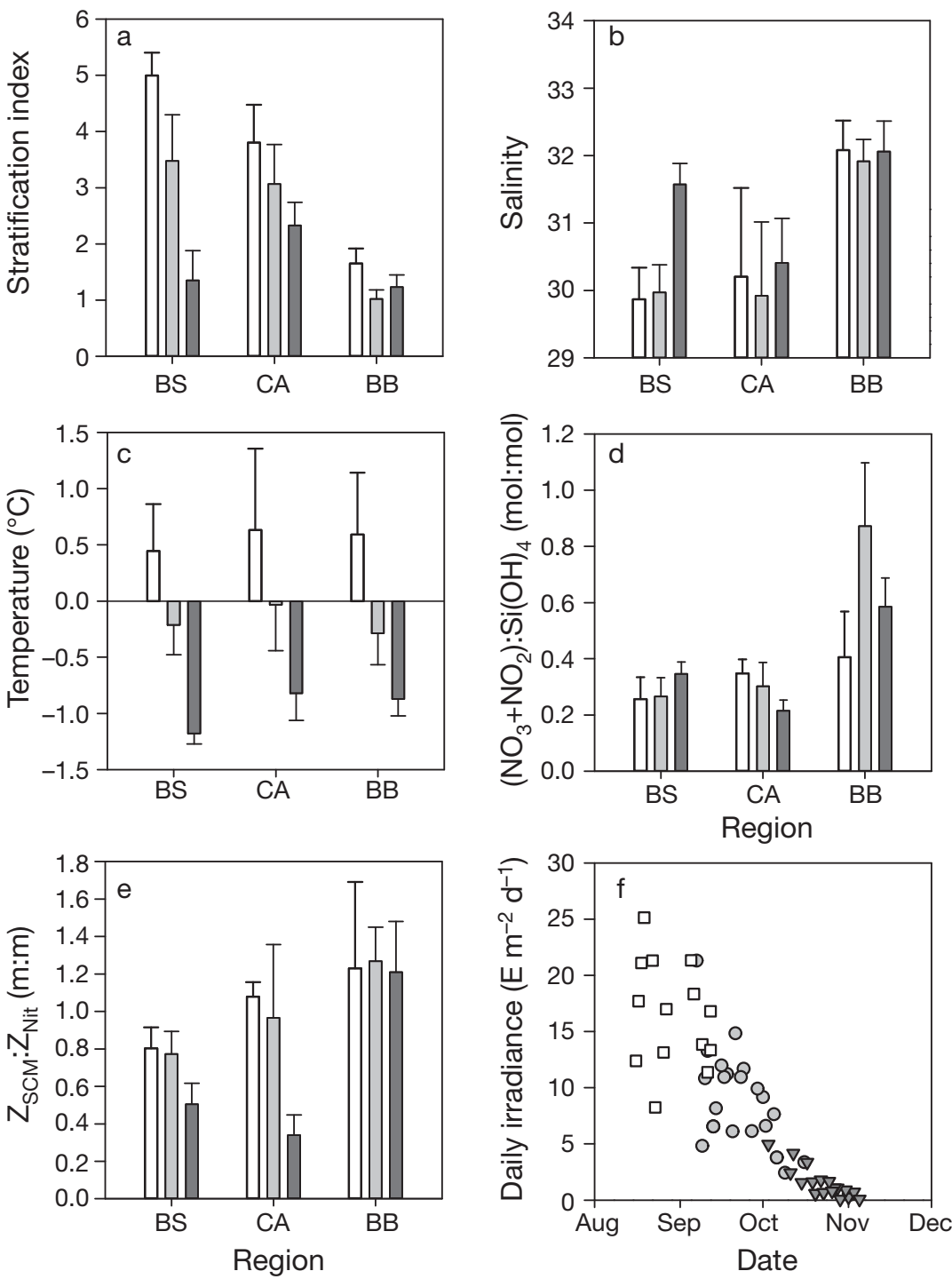

Fig. 2. Variations in (a) stratification index, (b) salinity averaged over the euphotic zone, (c) water temperature averaged over the euphotic zone, (d) $\left(\mathrm{NO}_{3}+\mathrm{NO}_{2}\right): \mathrm{Si}(\mathrm{OH})_{4}$ ratio at the depth of the maximum chlorophyll fluorescence, (e) ratio of the depth of subsurface chlorophyll a maximum to the nitracline $\left(\mathrm{Z}_{\mathrm{SCM}}: \mathrm{Z}_{\mathrm{Nit}}\right.$ ratio), and (f) daily incident irradiance across the Canadian High Arctic, during late summer 2005 (white), early fall 2006 (light gray), and fall 2007 (dark gray). In (a-e), bars and vertical lines represent mean and SE, respectively. BS: Beaufort Sea; CA: Canadian Arctic Archipelago; BB: Baffin Bay

significant regional or seasonal differences (Table 3). $\mathrm{NO}_{3}+\mathrm{NO}_{2}$ and $\mathrm{Si}(\mathrm{OH})_{4}$ concentrations were ca. 10 and 2 times higher at $Z_{\mathrm{SCM}}$ than at the sea surface, respectively. In contrast, $\mathrm{PO}_{4}$ concentrations at $\mathrm{Z}_{\mathrm{SCM}}$ were similar to those at the surface.

The daily incident irradiance was higher in Baffin Bay than in the Canadian Arctic Archipelago due to the difference in sampling periods, but decreased gradually from late summer 2005 to fall 2007 (Fig. 2f, Table 3). The stratification index was significantly higher in the Beaufort Sea than in Baffin Bay and, for all regions, was significantly lower in fall 2007 than in late summer 2005 (Fig. 2a, Tables 1 \& $3)$. Water temperature averaged over the euphotic zone ( $\mathrm{T}_{\text {eui }}$ Fig. $2 \mathrm{c}$ ) was lower, while percent sea ice coverage was higher, in fall 2007 than during the 2 previous sampling periods. The surface mixed layer $\left(Z_{m}\right)$ was deeper in fall 2007 than in late summer 2005 (Tables $1 \& 3$ ). During this study, there was no significant regional or seasonal difference in $Z_{\text {eu }}$ or in the ratio of $\mathrm{NO}_{3}+\mathrm{NO}_{2}$ to $\mathrm{PO}_{4}$ at $\mathrm{Z}_{\mathrm{SCM}}$ (Table 3).

\section{Spatio-temporal variability of biological variables in the Canadian High Arctic}

During the 3 sampling periods, total $(\geq 0.7 \mu \mathrm{m})$ and large $(\geq 5 \mu \mathrm{m})$ phytoplankton chl a biomass integrated over the euphotic zone was significantly higher in Baffin Bay than in the other regions (Fig. 3a,c,e, Table 3). Phytoplankton biomass was generally dominated by large cells $(\geq 5 \mu \mathrm{m})$ in Baffin Bay and by small cells $(0.7-5 \mu \mathrm{m})$ in the Beaufort Sea and the Canadian Arctic Archipelago (Fig. 3a,c,e). Particulate phytoplankton production by large $(\geq 5 \mu \mathrm{m})$ and small $(0.7-5 \mu \mathrm{m})$ cells integrated over the euphotic zone was significantly higher in Baffin Bay than in the Beaufort Sea during the 3 sampling years (Fig. 3b,d,f, Table 3). Primary production was generally dominated by small cells, except in Baffin Bay in fall 2007 (Fig. 3b,d,f). There was no significant difference in chl a biomass among the 3 sampling periods (Table 3). However, primary production by small cells was significantly higher in late summer 2005 than in early fall 2006 (Fig. 3b,d, Table 3). Maximum chl a biomass and primary production were observed in early fall 2006 and late summer 2005, respectively (Fig. 3b,c). During the 3 sampling periods, $\mathrm{Z}_{\mathrm{SCM}}$ was located at $26 \pm 18 \mathrm{~m}$ in the Beaufort Sea, $24 \pm 14 \mathrm{~m}$ in the Canadian Arctic Archipelago, and $37 \pm 25 \mathrm{~m}$ in Baffin Bay.

Except for the 2 westernmost stations where flagellates were numerically dominant, we observed a 

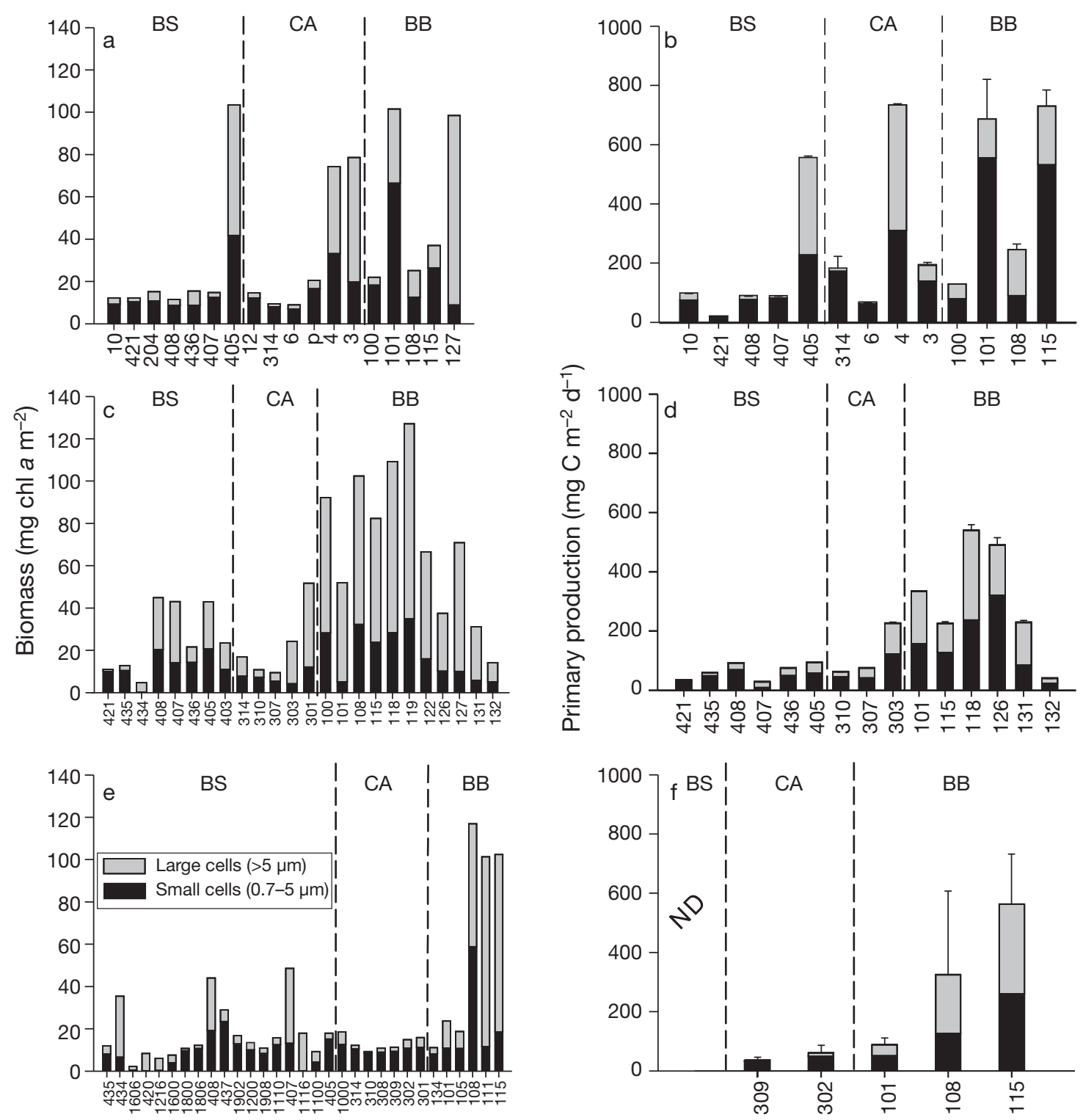

Station

Fig. 3. Variations in phytoplankton $(\mathrm{a}, \mathrm{c}, \mathrm{e})$ chlorophyll a $(\mathrm{chl} a)$ biomass and $(\mathrm{b}, \mathrm{d}, \mathrm{f})$ production for small $(0.7-5 \mu \mathrm{m})$ and large $(\geq 5 \mu \mathrm{m})$ cells integrated over the euphotic zone of stations across the Canadian High Arctic during (a, b) late summer 2005, $(c, d)$ early fall 2006, and (e, f) fall 2007. In $(b, d, f)$, vertical lines represent SD of estimated rates. BS: Beaufort Sea; CA:

Canadian Arctic Archipelago; BB: Baffin Bay; ND: no data available

mixed protist community in late summer 2005 and a community generally dominated by diatoms in early fall 2006 and by flagellates in fall 2007 (Fig. 4). In contrast to the 2 previous years, dinoflagellates were consistently observed in fall 2007, making up 1 to $23.4 \%$ of the relative abundance of total protists (Fig. 4c).

During the 3 sampling periods, the highest relative abundance of picophytoplankton was observed in the Beaufort Sea and Canadian Arctic Archipelago, whereas the highest relative abundance of micro- plankton was observed in Baffin Bay (Fig. 5). Picophytoplankton numerically dominated the phytoplankton community throughout the sampling area during late summer 2005 and fall 2007 (Fig. 5a,c). Photosynthetic picoeukaryotes made up between 50 and $100 \%$ of the total picophytoplankton abundance. The relative nanophytoplankton abundance was higher in early fall 2006 than in fall 2007 (Fig. 5b,c), whereas microplankton showed a higher relative abundance in early fall 2006 than in late summer 2005 (Fig. 5a,b). 

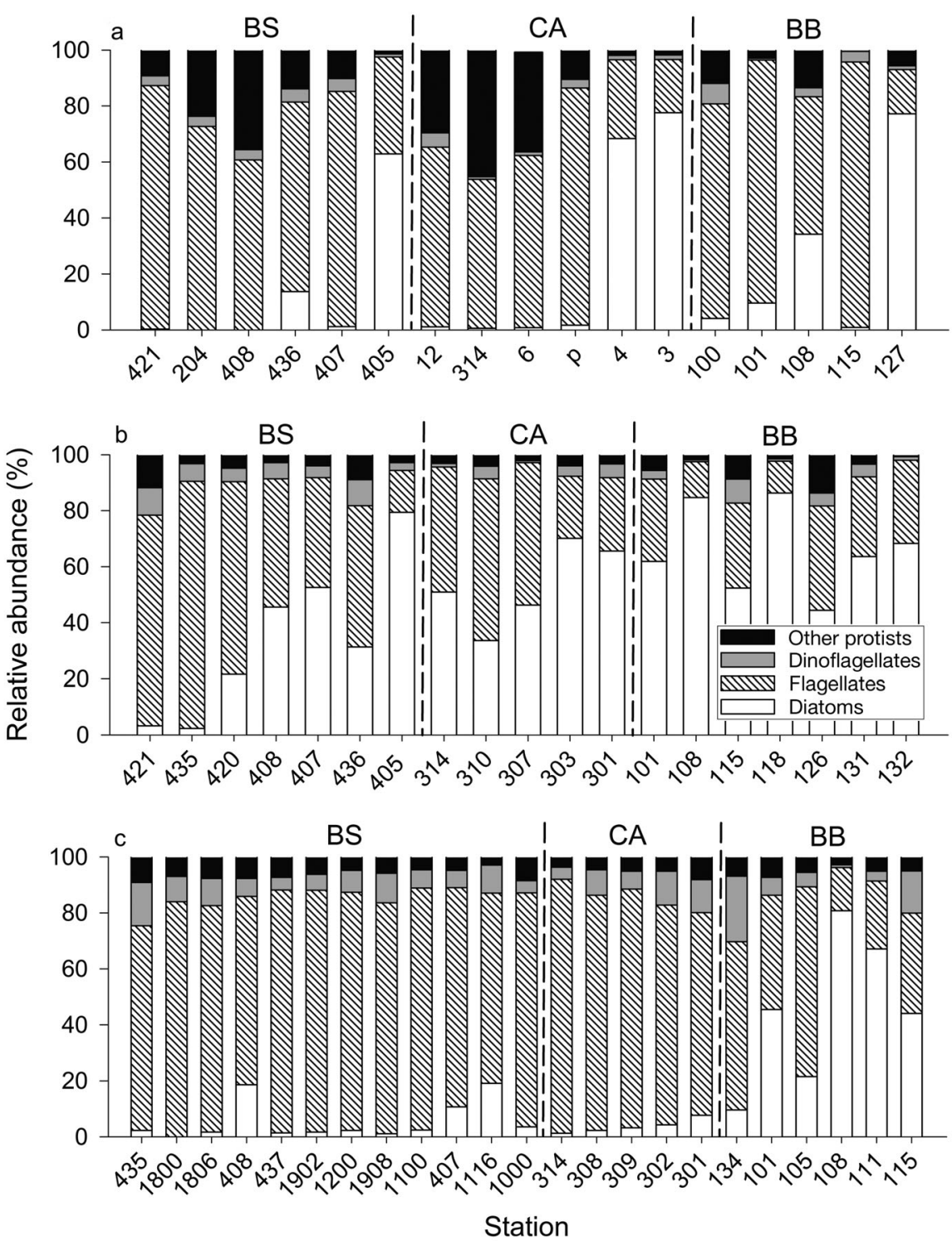

Fig. 4. Variations in relative abundance of 4 protist $(>2 \mu \mathrm{m})$ groups (diatoms, dinoflagellates, flagellates, and other protists $>2 \mu \mathrm{m}$ ) at the depth of the maximum chlorophyll fluorescence at stations across the Canadian High Arctic in (a) late summer 2005, (b) early fall 2006, and (c) fall 2007. Other protists comprise ciliates, choanoflagellates, and unidentified cells. BS: Beaufort Sea; CA: Canadian Arctic Archipelago; BB: Baffin Bay

In the Beaufort Sea, some deep stations $>200 \mathrm{~m}$ (Fig. 1) located in the central Amundsen Gulf (i.e. Stn 405 in 2005 and 2006; Stn 407 in 2006 and 2007; Stn 408 in 2006 and 2007; see box in Fig. 1) often showed higher chl a biomass ( $\geq 40 \mathrm{mg} \mathrm{m}^{-2}$ ) than surrounding stations (Fig. 3a,c,e). These stations were also characterized by high relative abundance of nanophytoplankton (Fig. 5) and diatoms (Fig. 4). Hereafter, this particular sector is referred to as the Amundsen Gulf hotspot.

\section{Multivariate analyses}

The cluster analysis identified 5 groups of taxonomically similar protist $(>2 \mu \mathrm{m})$ communities during the 3 yr sampling period in the Canadian High Arctic (ANOSIM, global $\mathrm{R}=$ 0.921, p $\leq 0.001$; Fig. 6, Table 4). Each station defined by its own location allowed the determination of a relative regional distribution for each of the 5 groups previously identified. Group I was largely dominated by unidentified flagellates $(91 \%)$ and comprised most of the stations in the eastern Beaufort Sea (89\%), Amundsen Gulf $(62 \%)$, and the central part of the Canadian Arctic Archipelago (67\%). Group II was mainly characterized by unidentified flagellates (65\%) followed by centric diatoms (26\%), and was composed of stations located outside $(39 \%)$ and inside $(25 \%)$ the Amundsen Gulf hotspot. Group III consisted of only 1 station (Stn 101) in Baffin Bay (visited in 2005) and was characterized by a distinct taxonomic composition, with unidentified flagellates $(53 \%)$, prymnesiophytes $(22 \%)$, and chrysophytes (14\%). Group IV consisted of centric diatoms (58\%) and unidentified flagellates (35\%), with stations mostly from the Amundsen Gulf hotspot (50\%) and Baffin Bay $(41 \%)$. Group V was dominated by centric diatoms $(76 \%)$ followed by unidentified flagellates $(17 \%)$, and comprised stations in Lancaster Sound (50\%), Baffin Bay (35\%), and the hotspot in Amundsen Gulf (25\%).

Constrained RDAs revealed 5 significant biological variables explaining $33.7 \%$ of the protist distribution throughout the Canadian High Arctic (Fig. 7a, Table 5). The eigenvalue of the first RDA axis $\left(\lambda_{1}=\right.$ $0.287)$ was significant $(\mathrm{p}<0.05)$ and explained $81.6 \%$ of the total variance in taxonomic groups in relation to biological variables, including size structure. The biomass of large phytoplankton $\left(\mathrm{B}_{\mathrm{L}}\right)$, relative abundances of picophytoplankton (Pico), nanophytoplankton (Nano), and microplankton (Micro) and production by large phytoplankton $\left(\mathrm{P}_{\mathrm{L}}\right)$ were strongly correlated with the first RDA axis $\left(r_{p}=0.83\right.$, 

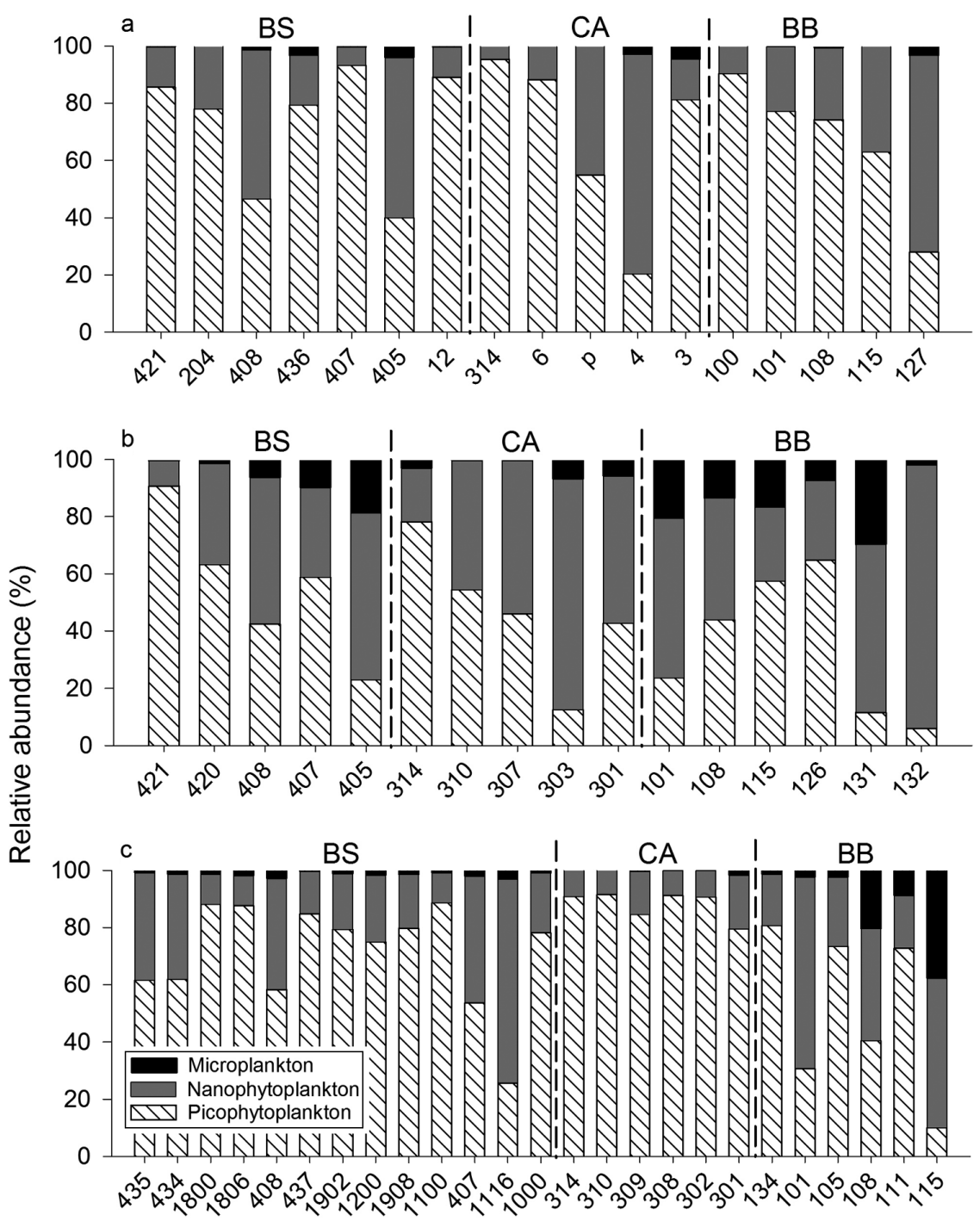

\section{Station}

Fig. 5. Variations in relative abundance of picophytoplankton $(<2 \mu \mathrm{m})$, nanophytoplankton $(2-20 \mu \mathrm{m})$, and microplankton $(\geq 20 \mu \mathrm{m})$ at the depth of the maximum chlorophyll fluorescence at stations across the Canadian High Arctic during (a) late summer 2005, (b) early fall 2006, and (c) fall 2007. BS: Beaufort Sea; CA: Canadian Arctic Archipelago; BB: Baffin Bay

phytoplankton, was predominantly observed at stations in the eastern Beaufort Sea, Amundsen Gulf, and the central part of the Canadian Arctic Archipelago. The eigenvalue of the second axis $\left(\lambda_{2}=0.02\right)$ of the redundancy analysis was not significant ( $p>0.05$, Fig. 7a).

Constrained RDA with environmental factors resulted in 8 significant variables accounting for $37.1 \%$ of the variation in taxonomic composition of protists (Fig. 7b, Table 5). The eigenvalue of the first 2 RDA axes $\left(\lambda_{1}=0.239, \lambda_{2}=0.066\right)$ were both significant $(\mathrm{p}<0.05)$ and explained $64.4 \%$ and $17.9 \%$ of the total variance in taxonomic groups of protists, respectively. $\mathrm{NO}_{3}+\mathrm{NO}_{2}$ concentrations at $\mathrm{Z}_{\mathrm{SCM}}, \mathrm{E}_{\mathrm{d}}, \mathrm{Z}_{\mathrm{SCM}}: \mathrm{Z}_{\mathrm{Nit}}, \mathrm{S}_{\mathrm{eu}}$, $\mathrm{I}_{\mathrm{C}}, \Delta \sigma_{\mathrm{t}}$, and $\mathrm{Z}_{\mathrm{BOT}}$ (bottom depth) were strongly correlated with the first RDA axis $\left(\mathrm{r}_{\mathrm{p}}\right.$ values of $-0.52,-0.46$, $-0.46,-0.33,0.32,0.32$, and 0.31 , respectively). The first RDA axis $\left(\lambda_{1}\right)$ explained the spatial variability in the Canadian High Arctic with distinct regional and intra-regional patterns associated with specific environmental variables. Highly productive regions, such as Baffin Bay, Lancaster Sound, and the Amundsen Gulf hotspot, were characterized by high values in $\mathrm{E}_{\mathrm{d}}, \mathrm{S}_{\mathrm{eu}}$ $\mathrm{Z}_{\mathrm{SCM}}: Z_{\mathrm{Nit}}$, and $\mathrm{NO}_{3}+\mathrm{NO}_{2}$ at $\mathrm{Z}_{\mathrm{SCM}}$. Regions showing a predominance of picophytoplankton cells (i.e. eastern Beaufort Sea, the Amundsen Gulf, and the central part of the Canadian Arctic Archipelago) were controlled by the stratification of the water col-

$-0.55,0.54,0.46$, and 0.26 , respectively). The first axis is associated with the distribution of centric and pennate diatoms in opposition to flagellated cells represented by unidentified flagellates, dinoflagellates, cryptophytes, prasinophytes, and prymnesiophytes. The relative abundance of diatoms was positively correlated with $\mathrm{B}_{\mathrm{L}}$ and $\mathrm{P}_{\mathrm{L}}$, corresponding to a high relative abundance of large-sized phytoplankton (Nano and Micro). This pattern was mainly found in Baffin Bay, Lancaster Sound, and the Amundsen Gulf hotspot. In contrast, high relative abundance of flagellates, linked to the pico-sized fraction of the umn. $\mathrm{NO}_{3}+\mathrm{NO}_{2}$ concentrations at $\mathrm{Z}_{\mathrm{SCM}}$ were positively correlated with $S_{\text {eu }}\left(r_{p}=0.39, p<0.001\right)$ and

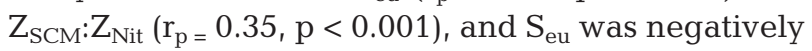
correlated with $\Delta \sigma_{t}\left(r_{p}=-0.59, p<0.001\right) . T_{e u}, E_{d}$, $\mathrm{NO}_{3}+\mathrm{NO}_{2}$ concentrations at $\mathrm{Z}_{\mathrm{SCM}}, \Delta \sigma_{\mathrm{t}}$, and $\mathrm{S}_{\mathrm{eu}}$ were highly correlated with the second RDA axis $\left(\mathrm{r}_{\mathrm{p}}\right.$ values of $0.53,0.39,-0.38,0.27$, and -0.25 , respectively). To a lesser extent, the second RDA axis $\left(\lambda_{2}\right)$ explained the temporal variability in the Canadian High Arctic. The late summer period (Fig. 7) was characterized by high values in $\mathrm{E}_{\mathrm{d}}, \mathrm{T}_{\text {eu }}$ and $\Delta \sigma_{\mathrm{t}}$. In contrast, the fall period (Fig. 7) was characterized by high $\mathrm{S}_{\mathrm{eu}}$ and the 


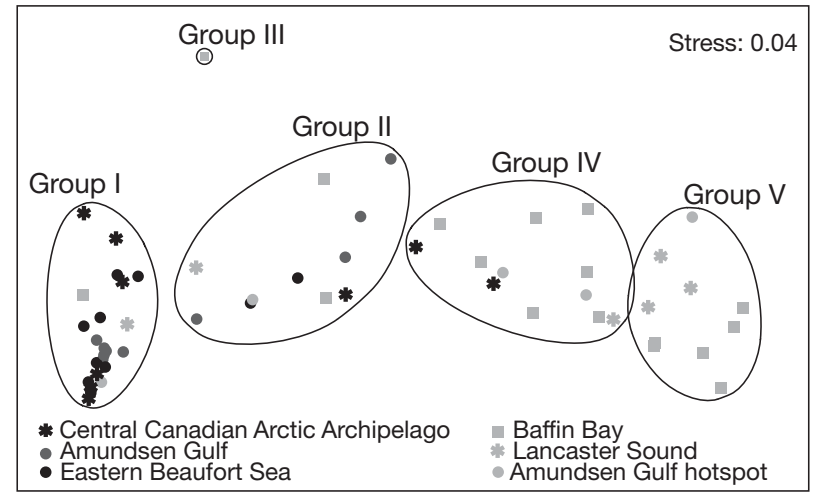

Fig. 6. Two-dimensional non-metric multidimensional scaling (MDS) of 58 stations across the Canadian High Arctic from 2005 to 2007 . The 5 groups of stations with taxonomically similar protist composition, as determined with the group-average clustering (at a similarity level of $80 \%$ ), are superimposed on the MDS

presence of sea ice. $\mathrm{T}_{\mathrm{eu}}$ was positively correlated with $\mathrm{E}_{\mathrm{d}}\left(\mathrm{r}_{\mathrm{p}}=0.38, \mathrm{p}<0.01\right)$ and negatively correlated with $\mathrm{I}_{\mathrm{C}}\left(\mathrm{r}_{\mathrm{p}}=-0.44, \mathrm{p}<0.01\right)$ and $\mathrm{S}_{\mathrm{eu}}\left(\mathrm{r}_{\mathrm{p}}=-0.30, \mathrm{p}<\right.$ $0.05)$. The $Z_{\mathrm{SCM}}: Z_{\mathrm{Nit}}$ ratio was positively correlated with $\mathrm{E}_{\mathrm{d}}\left(\mathrm{r}_{\mathrm{p}}=0.31, \mathrm{p}<0.05\right)$ and negatively correlated with $\mathrm{I}_{\mathrm{C}}\left(\mathrm{r}_{\mathrm{p}=}-0.30, \mathrm{p}<0.05\right)$.

\section{DISCUSSION}

\section{Distinct phytoplankton regimes in the Canadian High Arctic}

Sampling of 3 successive $3500 \mathrm{~km}$ transects in the Canadian High Arctic revealed that 2 key groups prevailed among phytoplankton communities:
(1) unidentified flagellates in the eastern Beaufort Sea, Amundsen Gulf, and the central part of the Canadian Arctic Archipelago, and (2) centric diatoms (mainly Chaetoceros spp., data not shown) in Baffin Bay, Lancaster Sound, and the Amundsen Gulf hotspot (Fig. 6, Table 4). The 2 communities were characterized by distinct phytoplankton size structure, biomass, and production (Fig. 7a, Table 5). Flagellate-based systems were characterized by relatively high abundance of picophytoplankton as well as low biomass and production of large cells. Previous studies have also shown that flagellates were numerically dominant in the western Arctic during the open water period (Hsiao et al. 1977, Schloss et al. 2008, Brugel et al. 2009) and were primarily supported by regenerated nutrients (Carmack et al. 2004, Simpson et al. 2008, Tremblay et al. 2008). In addition, flagellate-based systems have been reported in the deep Arctic basins (Legendre et al. 1993, Booth \& Horner 1997, Gosselin et al. 1997, Li et al. 2009). In contrast, diatom-based systems were characterized by relatively high abundance of nanophytoplankton and microplankton as well as high biomass and production of large cells. The diatombased systems have been described for different shelf and deep areas of the Arctic Ocean (von Quillfeldt 1997, Mostajir et al. 2001, Booth et al. 2002, Lovejoy et al. 2002, Hill et al. 2005), within which they were usually fuelled by new nitrogenous nutrients (e.g. Tremblay et al. 2002, Garneau et al. 2007).

Our results allowed us to distinguish 3 sub-regions in the Beaufort Sea: the eastern Beaufort Sea, the central Amundsen Gulf hotspot (see box in Fig. 1),

Table 4. Breakdown of similarities (\%) within groups of stations into contributions (\%) from each taxonomic group of protists. The percent number of stations from each region that are present in each group is also presented as occurrence (\%). Contribution and occurrence values $\geq 50 \%$ are in bold

\begin{tabular}{|c|c|c|c|c|c|}
\hline & Group I & Group II & Group III & Group IV & Group V \\
\hline \multirow[t]{3}{*}{ Taxonomic groups of protists } & \multicolumn{5}{|c|}{-Average similarity (\%) } \\
\hline & 88 & 84 & 100 (only 1 sample) & 85 & 82 \\
\hline & & & -Contribution ( $\%)$ & & \\
\hline Centric diatoms & & 26 & 9 & 58 & 76 \\
\hline Unidentified flagellates & 91 & 65 & 53 & 35 & 17 \\
\hline Prymnesiophytes & & & 22 & & \\
\hline Chrysophytes & & & 14 & & \\
\hline Sub-regions & & & _ Occurrence $(\%)$ & 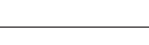 & \\
\hline Eastern Beaufort Sea & 89 & 11 & & & \\
\hline Amundsen Gulf (excluding hotspot stations) & 62 & 39 & & & \\
\hline Amundsen Gulf hotspot stations & & 25 & & 50 & 25 \\
\hline Central Canadian Arctic Archipelago & 67 & 11 & & 22 & \\
\hline Lancaster Sound & 17 & 17 & & 17 & 50 \\
\hline Baffin Bay & 6 & 12 & 6 & 41 & 35 \\
\hline
\end{tabular}


Table 5. Forward selection of biological and environmental variables influencing the distribution of phytoplankton communities in the Canadian High Arctic during 2005, 2006, and 2007 (Monte Carlo with 9999 unrestricted permutations, p $\leq 0.05$ ). Includes covariances, \% explained of (1) 5 biological variables $=33.7 \%$ and (2) 8 environmental variables $=37.1 \%$ ( $p=0.0001$, $\mathrm{n}=9999)$. $\mathrm{Z}_{\mathrm{SCM}}$ : depth of the subsurface chlorophyll a maximum, $Z_{\mathrm{Nit}}$ : nitracline

\begin{tabular}{|c|c|c|c|c|}
\hline Variable & Abbreviation & Eigenvalue & $\%$ explained & $\begin{array}{l}\mathrm{p} \text { value for unique explanation } \\
\qquad(\mathrm{n}=9999)\end{array}$ \\
\hline \multicolumn{5}{|c|}{ (1) Interaction of biological variables and phytoplankton groups } \\
\hline Biomass of large phytoplankton & $\mathrm{B}_{\mathrm{L}}$ & 0.257 & 25.7 & 0.0001 \\
\hline Picophytoplankton & Pico & 0.141 & 14.1 & 0.0001 \\
\hline Nanophytoplankton & Nano & 0.125 & 12.5 & 0.0002 \\
\hline Microplankton & Micro & 0.106 & 10.6 & 0.002 \\
\hline Production of large phytoplankton & $\mathrm{P}_{\mathrm{L}}$ & 0.103 & 10.3 & 0.0012 \\
\hline Total & & & 73.1 & \\
\hline \multicolumn{5}{|c|}{ (2) Interaction of environmental variables and phytoplankton groups } \\
\hline Nitrate plus nitrite & $\mathrm{NO}_{3}+\mathrm{NO}_{2}$ & 0.135 & 13.5 & 0.0001 \\
\hline Daily irradiance & $\mathrm{E}_{\mathrm{d}}$ & 0.112 & 11.2 & 0.0003 \\
\hline $\mathrm{Z}_{\mathrm{SCM}}: \mathrm{Z}_{\mathrm{Nit}}$ ratio & $\mathrm{Z}_{\mathrm{SCM}}: \mathrm{Z}_{\mathrm{Nit}}$ & 0.092 & 9.2 & 0.0006 \\
\hline Salinity ${ }^{\mathrm{a}}$ & $\mathrm{S}_{\mathrm{eu}}$ & 0.063 & 6.3 & 0.0084 \\
\hline Temperature & $\mathrm{T}_{\text {eu }}$ & 0.06 & 6 & 0.013 \\
\hline Sea ice coverage & $\mathrm{I}_{\mathrm{C}}$ & 0.059 & 5.9 & 0.01 \\
\hline Bottom depth & $\mathrm{Z}_{\mathrm{BOT}}$ & 0.058 & 5.8 & 0.013 \\
\hline Stratification index & $\Delta \sigma_{\mathrm{t}}$ & 0.058 & 5.8 & 0.011 \\
\hline Total & & & 63.7 & \\
\hline${ }^{a}$ Averaged over the euphotic zone & & & & \\
\hline
\end{tabular}
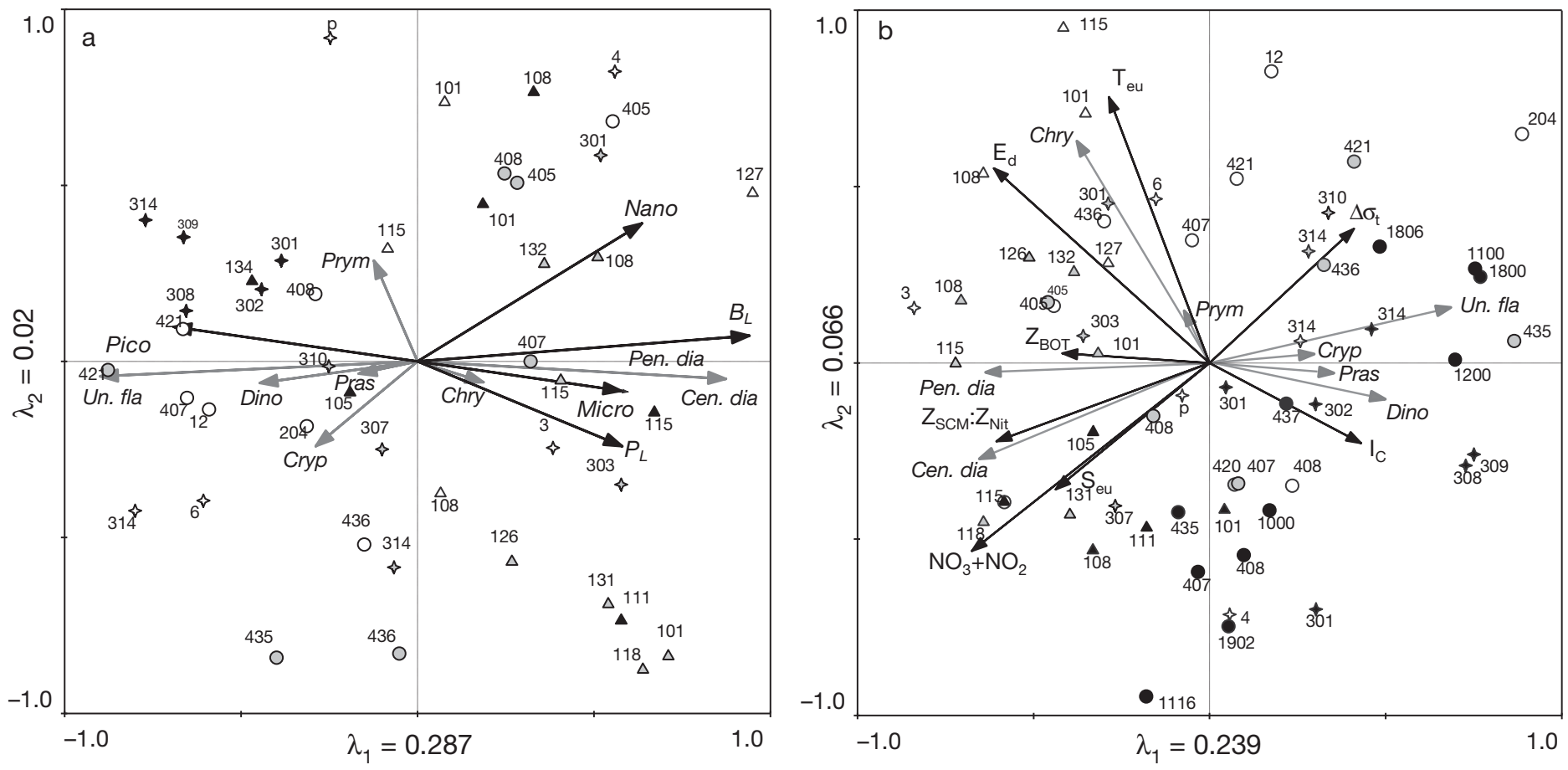

Fig. 7. Redundancy analysis (RDA) ordination plots of Axes I and II showing taxonomic groups of protists (gray arrows) in relation to (a) biological (black arrows) and (b) environmental (black arrows) variables for stations across the Canadian High Arctic during late summer 2005 (white), early fall 2006 (gray), and fall 2007 (black). Symbols represent different regions: Beaufort Sea: circle; Canadian Arctic Archipelago: star; Baffin Bay: triangle. Full names of biological and environmental variables are listed in Table 5. Cen. dia: centric diatoms; Chry: chrysophytes; Cryp: cryptophytes; Dino: dinoflagellates; Pen. dia: pennate diatoms; Pras: prasinophytes; Prym: prymnesiophytes; Un. fla: unidentified flagellates. In (a), the arrows for centric and pennate diatoms are superimposed 
and the remainder of the Amundsen Gulf. During the 3 sampling years, the eastern Beaufort Sea, including the Mackenzie shelf, was characterized by low total phytoplankton chl a biomass (mean $\pm \mathrm{SD} ; 16.0 \pm$ $\left.5.5 \mathrm{mg} \mathrm{m}^{-2}\right)$ and production $\left(73 \pm 37 \mathrm{mg} \mathrm{C} \mathrm{m}^{-2} \mathrm{~d}^{-1}\right)$ in the euphotic zone. Unlike the Amundsen Gulf hotspot, other sites of the Amundsen Gulf showed low total phytoplankton chl a biomass $(19.4 \pm 4.6 \mathrm{mg}$ $\left.\mathrm{m}^{-2}\right)$ and production $\left(49 \pm 38 \mathrm{mg} \mathrm{C} \mathrm{m}^{-2} \mathrm{~d}^{-1}\right)$, comparable to values in the eastern Beaufort Sea. The Amundsen Gulf hotspot had the highest total phytoplankton chl a biomass $\left(46.6 \pm 5.7 \mathrm{mg} \mathrm{m}^{-2}\right)$ and production $\left(159 \pm 123 \mathrm{mg} \mathrm{C} \mathrm{m}^{-2} \mathrm{~d}^{-1}\right)$ of the Beaufort Sea region. Phytoplankton biomass and production were generally dominated by small cells $(<5 \mu \mathrm{m})$ in the eastern Beaufort Sea and Amundsen Gulf, whereas phytoplankton biomass was dominated by large cells in the Amundsen Gulf hotspot. High abundances of zooplankton (Forest et al. 2011a) and polar cod (Geoffroy et al. 2011) have also been observed in the latter area. Observed values of phytoplankton biomass and production compare with values previously reported for the eastern Beaufort Sea (40 to $100 \mathrm{mg} \mathrm{C}$ $\mathrm{m}^{-2} \mathrm{~d}^{-1}$ in August, Carmack et al. $2004 ; 10.5$ to

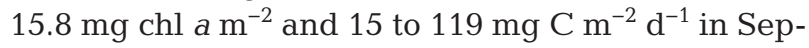
tember-October, Brugel et al. 2009) and the Amundsen Gulf (90 to $117 \mathrm{mg} \mathrm{C} \mathrm{m}^{-2} \mathrm{~d}^{-1}$ in July-August, Juul-Pedersen et al. 2010; 92 to $105 \mathrm{mg} \mathrm{C} \mathrm{m}^{-2} \mathrm{~d}^{-1}$ in September-October, Brugel et al. 2009).

The Canadian Arctic Archipelago can be divided into 2 distinct sub-regions consisting of the central part of the Archipelago and Lancaster Sound to the east. The central part of the Archipelago was mainly characterized by low total phytoplankton biomass

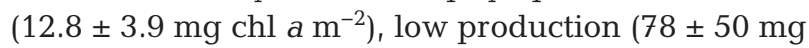
$\left.\mathrm{C} \mathrm{m}^{-2} \mathrm{~d}^{-1}\right)$, and a high relative abundance of small cells. In contrast, Lancaster Sound was characterized by high biomass $\left(39.7 \pm 17.3 \mathrm{mg} \mathrm{chl} \mathrm{a} \mathrm{\textrm {m } ^ { - 2 }}\right)$, high production $\left(251 \pm 203 \mathrm{mg} \mathrm{C} \mathrm{m}^{-2} \mathrm{~d}^{-1}\right)$, and a high relative abundance of large cells. This agrees with previous evidence that Lancaster Sound is a highly productive hotspot for several trophic levels (Michel et al. 2006), including phytoplankton and ice algae (Borstad \& Gower 1984, Michel et al. 1996), zooplankton, polar cod (Welch et al. 1992, Crawford \& Jorgenson 1996), birds, and the benthos (Thomson 1982).

Throughout the study area, Baffin Bay had the highest total phytoplankton biomass $(64.1 \pm 7.3 \mathrm{mg}$ chl $\left.a \mathrm{~m}^{-2}\right)$ and production $\left(361 \pm 75 \mathrm{mg} \mathrm{C} \mathrm{m}^{-2} \mathrm{~d}^{-1}\right)$, both dominated by large cells, and comparable to values previously reported for summer and early fall (41 to $68 \mathrm{mg} \mathrm{chl} \mathrm{a} \mathrm{m}{ }^{-2}$ and 550 to $1719 \mathrm{mg} \mathrm{C} \mathrm{m}^{-2} \mathrm{~d}^{-1}$, Klein et al. 2002). This region is described as the most productive marine system north of the Arctic Circle (Tremblay et al. 2006) in terms of primary production (Klein et al. 2002, Tremblay et al. 2002), zooplankton abundance (Acuña et al. 2002), and seabird (Karnovsky \& Hunt 2002) and marine mammal (Stirling 1997) populations. The overall results of the present study clearly indicate that pelagic diatom-based systems in the Canadian Arctic lead to efficient energy transfer to upper trophic levels and carbon export towards deeper water compared to flagellatebased systems, which have longer food chains (Fenchel 1988, Cushing 1989).

Based on the composition, size structure, biomass, and production of the communities, 2 phytoplankton regimes (i.e. flagellate- and diatom-based systems) and 6 sub-regions (i.e. eastern Beaufort Sea, Amundsen Gulf, Amundsen Gulf hotspot, central Canadian Arctic Archipelago, Lancaster Sound, and Baffin Bay) were distinguished across the Canadian High Arctic from late summer to fall. Tremblay et al. (2009) described the heterogeneous distribution of phytoplankton across the Canadian High Arctic in late summer. The highest abundance of picophytoplankton was observed in the Beaufort Sea/Northwest Passage region, whereas nanophytoplankton increased numerically toward the eastern Canadian Arctic. Clearly, our analysis provides an improved framework to understand the structure and function of marine phytoplankton communities as well as the fundamental processes influencing the transfer of carbon to higher trophic levels and to depth in coastal Arctic seas.

\section{Influence of environmental factors on phytoplankton regimes}

\section{Spatial variability}

The environmental factors explaining the variability in phytoplankton communities and regimes were nutrient concentrations (especially $\mathrm{NO}_{3}+\mathrm{NO}_{2}$ ) at the base of $Z_{e u}$ incident irradiance, and the $Z_{\mathrm{SCM}}: Z_{\text {Nit }}$ ratio (Fig. 7b, Table 5). Flagellate-based systems were associated with relatively fresh $\left(\mathrm{S}_{\text {eu }}\right.$ 25.77 to 33.44) and stratified oligotrophic $\left(\mathrm{NO}_{3}+\mathrm{NO}_{2}\right.$ depleted) waters (e.g. Beaufort Sea, central Canadian Arctic Archipelago), whereas diatom-based systems were associated with more saline ( $\mathrm{S}_{\text {eu }}, 29.88$ to 33.27) and well-mixed eutrophic $\left(\mathrm{NO}_{3}+\mathrm{NO}_{2}\right.$ repleted) waters (e.g. Baffin Bay, Lancaster Sound, Amundsen Gulf hotspot). Hence, a transition from flagellate- to diatom-based systems was mainly controlled by ver- 
tical mixing, which governed the supply of nutrients to surface waters. The $\left(\mathrm{NO}_{3}+\mathrm{NO}_{2}\right): \mathrm{Si}(\mathrm{OH})_{4}$ and $\left(\mathrm{NO}_{3}+\mathrm{NO}_{2}\right): \mathrm{PO}_{4}$ ratios were lower than RedfieldBrzezinski values at most stations (Fig. 2d, Table 1), indicating that dissolved inorganic nitrogen was the potentially limiting macronutrient throughout the sampling region. In Baffin Bay, however, $\left(\mathrm{NO}_{3}+\mathrm{NO}_{2}\right): \mathrm{Si}(\mathrm{OH})_{4}$ ratios $>1$ and low $\mathrm{Si}(\mathrm{OH})_{4}$ concentrations (data not shown) indicate potential silicon limitation, as previously reported (Michel et al. 2002, Tremblay et al. 2002). Our results also agree with those of Carmack (2007), showing a longitudinal gradient in vertical stratification decreasing from the Beaufort Sea to Baffin Bay through the Canadian Arctic Archipelago (Fig. 7b). In the oligotrophic waters of the Beaufort Sea and Canada Basin (Carmack et al. 2004, Lee \& Whitledge 2005, Simpson et al. 2008, Tremblay et al. 2008), the numerical dominance of the small prasinophyte Micromonas Manton et Parke was explained by strong surface density gradients (Li et al. 2009, Tremblay et al. 2009). Therefore, the structure and functioning of Arctic phytoplankton regimes appears to be determined by similar drivers, i.e. vertical stratification and nutrient availability, as in tropical and temperate marine systems (Margalef 1978, Margalef et al. 1979, Cullen et al. 2002).

The vertical position of the maximum chl a fluorescence relative to the nitracline differed between the 2 phytoplankton regimes (Fig. 7b), possibly reflecting differences in phytoplankton adaptive strategies. In stratified oligotrophic regions (i.e. eastern Beaufort Sea, Amundsen Gulf and the central part of the Canadian Arctic Archipelago), $Z_{\mathrm{SCM}}$ was above the nitracline $\left(Z_{\mathrm{SCM}}: Z_{\mathrm{Nit}}<1\right.$; Fig. 2e). This pattern was also observed in stratified temperate waters (Venrick 1988), where aggregated phytoplankton communities, generally dominated by flagellates, were called 'layer-formers' by Cullen \& MacIntyre (1998). Different adaptive mechanisms were proposed to explain this phytoplankton layer formation: (1) efficient nutrient consumption near the surface (Cullen \& MacIntyre 1998), (2) physiological control of buoyancy, and (3) grazer avoidance (Turner \& Tester 1997, Lass \& Spaak 2003, van Donk et al. 2011). In wellmixed eutrophic regions (i.e. Baffin Bay and Lancaster Sound), the position of $Z_{\mathrm{SCM}}$ was located near or below the nitracline $\left(Z_{\mathrm{SCM}}: Z_{\mathrm{Nit}} \geq 1\right)$. In this case, the phytoplankton layer was thicker and dominated by diatoms, a pattern described for 'mixers' by Cullen \& MacIntyre (1998). These 'mixers' are adapted to grow under variable light intensity (Demers et al. 1991, Ibelings et al. 1994, Cullen \& MacIntyre 1998). In accordance with Martin et al. (2010), these find- ings suggest that the vertical stratification, through its determinant influence on upward nutrient fluxes, determines the intensity, shape, and phytoplankton communities of the subsurface chlorophyll maxima in the Canadian Arctic. The $Z_{\mathrm{SCM}}: Z_{\mathrm{Nit}}$ ratio is therefore a useful predictor of phytoplankton communities and regimes observed at the depth of maximum chl a fluorescence, the latter being a common feature in ice-free Arctic waters during late summer and early fall (Hill et al. 2005, Martin et al. 2010, McLaughlin \& Carmack 2010).

In addition to the large-scale phytoplankton regimes described above, highly productive hotspots (e.g. central Amundsen Gulf, Lancaster Sound) reflect the influence of smaller-scale processes on biological systems. In the Amundsen Gulf, hydrodynamic singularities and forcing events such as upwellings, anticyclonic eddies, and storms have been identified as key forcings (Carmack \& Chapman 2003, Tremblay et al. 2008, Williams \& Carmack 2008). Interestingly, remote sensing studies have documented recurrent locations of oceanic fronts in the Beaufort Sea (Belkin et al. 2009), including the hotspot in the central Amundsen Gulf (Belkin et al. 2003, Ben Mustapha et al. 2010). Strongly supported by $11 \mathrm{yr}$ of satellite observations of surface temperature (1998 to 2008), 6 zones of enhanced horizontal thermal gradients were described and related to these forcing events (Ben Mustapha et al. 2010). Our results show enhanced biological productivity that coincides with the location of the oceanic front described in the central Amundsen Gulf by Belkin et al. (2003) and Ben Mustapha et al. (2010). Another well-documented oceanic front to the west of Cape Bathurst is associated with upwelling episodes due to the combined effect of wind forcing and isobath divergence (Belkin et al. 2003, Ben Mustapha et al. 2010), and sustains high biological productivity (Williams \& Carmack 2008). This study and others reveal that productive hotspots occur throughout the coastal Canadian Arctic, yet their contribution to total primary production still remains to be determined.

\section{Temporal variability}

Our study demonstrates that a fall bloom was a widespread feature throughout the Canadian High Arctic, as shown by the high chl a biomass and high relative abundance of nanophytoplankton and microplankton as well as centric diatoms (Chaetoceros spp.; Figs. 3b, 4b \& 5b). The occurrence of fall blooms has been documented in the Cape Bathurst 
polynya (Arrigo \& van Dijken 2004, Forest et al. 2008) and in the North Water (Booth et al. 2002, Caron et al. 2004), but has not been reported previously in other regions of the Canadian High Arctic. Fall blooms are expected in polynyas since their notoriously long open-water period allows the phytoplankton to exploit a portion of the nutrients supplied by the late season increase in convective mixing and upwelling (Tremblay \& Smith 2007, Williams et al. 2007). The occurrence of these blooms elsewhere is more surprising and might be linked to the ongoing and widespread contraction of the ice-covered season, driven by late freeze-up rather than early melt (Howell et al. 2009, Markus et al. 2009, Tivy et al. 2011).

From late summer to fall, the relative abundance of chrysophytes and prymnesiophytes decreased coincidentally with the seasonal decline in incident irradiance and water temperature (Fig. 7b). Similar trends in the carbon biomass of these 2 flagellate groups were observed in the Gulf of Bothnia (Baltic Sea) from August to October (Andersson et al. 1996). In fall, the relative abundance of dinoflagellates (mainly Gymnodinium/Gyrodinium) increased in parallel to the sea ice cover formation (Fig. $7 b$, Table 3). These phagotrophic dinoflagellates, which were present throughout our study, were likely grazing on phytoplankton cells. This hypothesis is supported by results of Levinsen \& Nielsen (2002) and Hansen et al. (2003), showing significant ingestion of primary production by microzooplankton towards the end of blooms in the West Greenland and Baltic Seas. More studies are needed to better improve our understanding of the influence of environmental factors and grazing pressure on Arctic phytoplankton communities.

\section{Ongoing responses of Arctic phytoplankton communities in a changing climate}

Uncertainties and divergences remain with respect to the responses of Arctic phytoplankton dynamics to climate change (Behrenfeld et al. 2006, Arrigo et al. 2008, Vetrov \& Romankevich 2009, Boyce et al. 2010, 2011, Arigo \& van Dijken 2011). The present study highlights the biogeographic complexity and the existence of distinct phytoplankton regimes in the Canadian High Arctic (flagellate- versus diatombased systems). In this context, it is essential to take into account that each biogeographic region of the Arctic may respond differently to climate change.

Based on the classification of phytoplankton regimes defined earlier, we investigated the relation- ship between phytoplankton biomass in eutrophic and oligotrophic waters and sea ice coverage, using data at each station sampled from 2005 to 2010 (Fig. 8). Eutrophic regions considered are Baffin Bay, Lancaster Sound, and the Amundsen Gulf hotspot. Oligotrophic regions are the eastern Beaufort Sea, peripheral Amundsen Gulf, and the central Canadian Arctic Archipelago. This analysis demonstrates that phytoplankton chl a biomass increases significantly with decreasing sea ice coverage in eutrophic and oligotrophic waters (Fig. 8). However, the increase in phytoplankton biomass (i.e. the slope of the regression) is much higher in eutrophic waters. These different responses of eutrophic versus oligotrophic regions to the sea ice cover may provide interesting explanations to the divergent predictions with respect to future primary production in the Arctic Ocean (e.g. Arrigo et al. 2008, Li et al. 2009, Vetrov \& Romankevich 2009, Lavoie et al. 2010). In accordance with Lavoie et al. (2010), a lengthening of the growing season would not induce a substantial increase in phytoplankton production and biomass in oligotrophic regions, due to persistent nutrient limitation. However, the increase in the frequency and intensity of storms at high latitudes (McCabe et al. 2001, Zhang et al. 2004, Yang 2009) suggests that episodic vertical mixing events will be more frequent

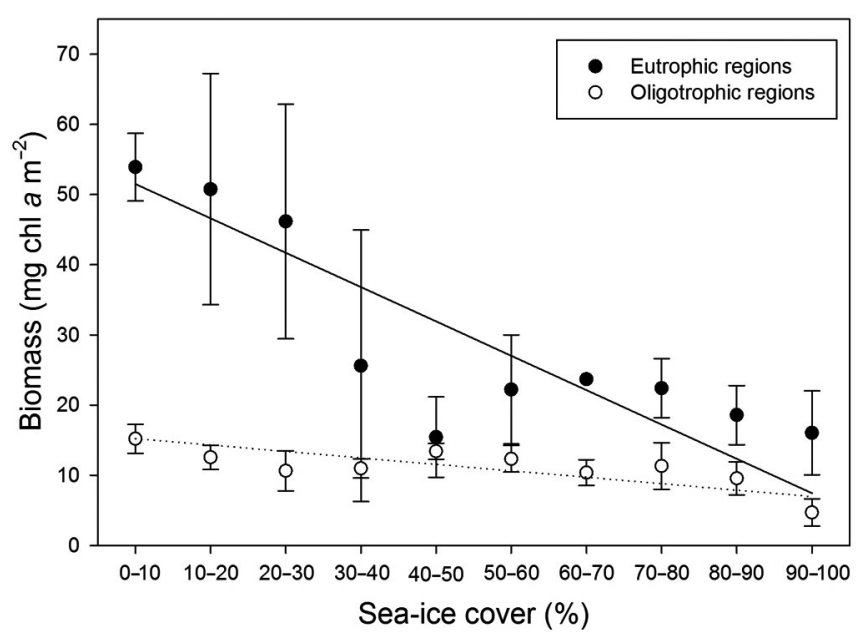

Fig. 8. Relationship between sea ice coverage and phytoplankton chlorophyll a (chl a) biomass integrated over the euphotic zone for eutrophic (i.e. Baffin Bay, Lancaster Sound, and Amundsen Gulf hotspot) and oligotrophic regions (i.e. Beaufort Sea, Amundsen Gulf, and central Canadian Archipelago) from 2005 to 2010. Bars and vertical lines represent mean and SE, respectively. Model II linear regressions: $x_{2}=-0.49 x_{1}+53.94, r^{2}=0.72, p<0.01$ (eutrophic regions; black circle, solid line) and $x_{2}=-0.09 x_{1}+15.71, r^{2}=$ $0.57, \mathrm{p}<0.01$ (oligotrophic regions; white circle, dotted line) 
in the future. Such changes in the stability of the water column could increase potential nutrient replenishment to surface waters, supporting episodic events of enhanced primary production in oligotrophic regions. For example, Tremblay et al. (2011) showed that the sea ice minima of 2007-2008 and upwelling-favorable winds in the southeast Beaufort Sea have synergistically resulted in a substantial increase in marine pelagic and benthic productivity (see also Forest et al. 2011b). Our results also point to enhanced primary production as a result of the lengthening of the growing season in eutrophic regions. In productive regions, annual primary production appears to be controlled by the photoperiod, as previously shown by Rysgaard et al. (1999). Altogether, the combined effect of a global increase in vertical stratification and lengthening of the growing season could alter the functioning and structure of eutrophic regions (i.e. diatom-based system), shifting to characteristics similar to oligotrophic regions (i.e. flagellate-based system). There is recent evidence that picophytoplankton-based systems, favored by warm temperature and strong vertical stratification of the upper water column, are becoming more dominant in the Arctic Ocean (Li et al. 2009). Tremblay et al. (2009) also found a positive correlation between picophytoplankton abundance and water temperature in the circumpolar Arctic. In addition, changes in archaeal and bacterial composition in the Arctic Ocean indicate that the microbial component has become more active and persistent, with a negative impact on the ecological efficiency of carbon transfer between phytoplankton communities and higher trophic levels (Kirchman et al. 2009). Interestingly, episodes of significant increases of jellyfish biomass favored by warmer sea surface temperature and low sea ice cover were reported in the Bering Sea throughout the 1990s (Brodeur et al. 2002, 2008). It has been shown that these jellyfish blooms could induce major shifts in microbial structure and function, diverting carbon toward bacterial $\mathrm{CO}_{2}$ production and away from higher trophic levels (Purcell et al. 2010, Condon et al. 2011). Highly productive regions, crucial to carbon and energy transfers in Arctic marine ecosystems, are strikingly sensitive to projected changes in the stability of the water column (Steinacher et al. 2010) and ocean acidification (Steinacher et al. 2009). Changes in these regions could alter the carbon flow to higher trophic levels and the capacity of the Arctic Ocean to act as a $\mathrm{CO}_{2}$ pump, especially given the predicted increase in plankton respiration in a warmer spring-summer Arctic (Vaquer-Sunyer et al. 2010).
Acknowledgements. This project was supported by grants from ArcticNet (Network of Centres of Excellence of Canada), the Canadian International Polar Year Federal Program Office, the Natural Sciences and Engineering Research Council of Canada, the Canadian Museum of Nature, and Fisheries and Oceans Canada. Partial operating funds for the CCGS 'Amundsen' were provided by the International Joint Ventures Fund of the Canada Foundation for Innovation and the Fonds québécois de la recherche sur la nature et les technologies. M.A. received a postgraduate scholarship from the Institut des sciences de la mer de Rimouski (ISMER) and stipends from ArcticNet and Québec-Océan. We gratefully acknowledge the officers and crew of the CCGS 'Amundsen' for their invaluable support during expeditions. We are especially indebted to G. Tremblay, M. Simard, K. Proteau, J. Ferland, L. Bourgeois, B. LeBlanc, K. Randall, M. Blais, and A. Baya for technical assistance in the field and laboratory; J. Gagnon for nutrient analysis; G. Tremblay for cell identification and enumeration; C. Belzile for help during flow cytometric analysis; and P. Guillot for processing the CTD data. We also thank Y. Gratton for providing physical data and G. Ferreyra, A. Forest, M. Levasseur, C.J. Mundy, and 2 anonymous reviewers for constructive comments on the manuscript. This is a contribution to the research programs of ArcticNet, Circumpolar Flaw Lead system study, ISMER, the Freshwater Institute (Fisheries and Oceans Canada), and Québec-Océan.

\section{LITERATURE CITED}

ACIA (Arctic Climate Impact Assessment) (2005) Arctic climate impact assessment: scientific report. Cambridge University Press, Cambridge

Acuña JL, Deibel D, Saunders PA, Booth B and others (2002) Phytoplankton ingestion by appendicularians in the North Water. Deep-Sea Res II 49:5101-5115

> Andersson A, Hajdu S, Haecky P, Kuparinen J, Wikner J (1996) Succession and growth limitation of phytoplankton in the Gulf of Bothnia (Baltic Sea). Mar Biol 126: 791-801

> Arrigo KR, van Dijken GL (2004) Annual cycles of sea ice and phytoplankton in Cape Bathurst polynya, southeastern Beaufort Sea, Canadian Arctic. Geophys Res Lett 31: L08304. doi:10.1029/2003GL018978

Arrigo KR, van Dijken GL (2011) Secular trends in Arctic Ocean net primary production. J Geophys Res 116: C09011. doi:10.1029/2011JC007151

Arrigo KR, van Dijken G, Pabi S (2008) Impact of a shrinking Arctic ice cover on marine primary production. Geophys Res Lett 35:L19603. doi:10.1029/2008GL035028

Azam F, Fenchel T, Field JG, Gray JS, Meyer-Reil LA, Thingstad F (1983) The ecological role of water-column microbes in the sea. Mar Ecol Prog Ser 10:257-263

Barber DG, Lukovich JV, Keogak J, Baryluk S, Fortier L, Henry GHR (2008) The changing climate of the Arctic. Arctic 61:7-26

Behrenfeld MJ (2011) Uncertain future for ocean algae. Nat Clim Change 1:33-34

Behrenfeld MJ, O'Malley RT, Siegel DA, McClain CR and others (2006) Climate-driven trends in contemporary ocean productivity. Nature 444:752-755

Belkin IM, Cornillon PC, Ullman D (2003) Ocean fronts around Alaska from satellite SST data. Proc Am Meteorol Soc 7th Conf Polar Meteorol Oceanogr, Hyannis, MA, 
Paper 12.7

Belkin IM, Cornillon PC, Sherman K (2009) Fronts in large marine ecosystems. Prog Oceanogr 81:223-236

Ben Mustapha S, Larouche P, Dubois JMM (2010) Do AVHRR-sea surface temperature fronts in the Beaufort Sea reveal biological hotspots? Proc IGARSS2010, Honolulu, HI, 25-30 July 2010

Bérard-Therriault L, Poulin M, Bossé L (1999) Guide d'identification du phytoplancton marin de l'estuaire et du golfe du Saint-Laurent incluant également certains protozoaires. Publ Spéc Can Sci Halieut Aquat 128

Booth BC, Horner RA (1997) Microalgae on the Arctic Ocean section, 1994: species abundance and biomass. DeepSea Res II 44:1607-1622

Booth BC, Larouche P, Bélanger S, Klein B, Amiel D, Mei ZP (2002) Dynamics of Chaetoceros socialis blooms in the North Water. Deep-Sea Res II 49:5003-5025

Borstad GA, Gower JFR (1984) Phytoplankton chlorophyll distribution in the eastern Canadian Arctic. Arctic 37: 226-233

Boyce DG, Lewis MR, Worm B (2010) Global phytoplankton decline over the past century. Nature 466:591-596

> Boyce DG, Lewis MR, Worm B (2011) Boyce et al. reply. Nature 472:E8-E9

> Brodeur RD, Sugisaki H, Hunt GL Jr (2002) Increases in jellyfish biomass in the Bering Sea: implications for the ecosystem. Mar Ecol Prog Ser 233:89-103

> Brodeur RD, Decker MB, Ciannelli L, Purcell JE and others (2008) The rise and fall of jellyfish in the Bering Sea in relation to climate regime shifts. Prog Oceanogr 77: 103-111

> Brugel S, Nozais C, Poulin M, Tremblay JÉ and others (2009) Phytoplankton biomass and production in the southeastern Beaufort Sea in autumn 2002 and 2003. Mar Ecol Prog Ser 377:63-77

- Brzezinski MA (1985) The Si:C:N ratio of marine diatoms: interspecific variability and the effect of some environmental variables. J Phycol 21:347-357

Cai WJ, Chen L, Chen B, Gao Z and others (2010) Decrease in the $\mathrm{CO}_{2}$ uptake capacity in an ice-free Arctic Ocean basin. Science 329:556-559

Carmack EC (2007) The alpha/beta ocean distinction: a perspective on freshwater fluxes, convection, nutrients and productivity in high-latitude seas. Deep-Sea Res II 54: 2578-2598

> Carmack EC, Chapman DC (2003) Wind-driven shelf/basin exchange on an Arctic shelf: the joint roles of ice cover extent and shelf-break bathymetry. Geophys Res Lett 30: 1778. doi:10.1029/2003GL017526

Carmack EC, Macdonald RW (2002) Oceanography of the Canadian shelf of the Beaufort Sea: a setting for marine life. Arctic 55:29-45

> Carmack EC, McLaughlin FA (2011) Towards recognition of physical and geochemical change in Subarctic and Arctic Seas. Prog Oceanogr 90:90-104

> Carmack EC, Wassmann P (2006) Food webs and physicalbiological coupling on pan-Arctic shelves: unifying concepts and comprehensive perspectives. Prog Oceanogr 71:446-477

> Carmack EC, Macdonald RW, Jasper S (2004) Phytoplankton productivity on the Canadian Shelf of the Beaufort Sea. Mar Ecol Prog Ser 277:37-50

Caron G, Michel C, Gosselin M (2004) Seasonal contributions of phytoplankton and fecal pellets to the organic carbon sinking flux in the North Water (northern Baffin
Bay). Mar Ecol Prog Ser 283:1-13

Chavez FP, Messié M, Pennington JT (2011) Marine primary production in relation to climate variability and change. Annu Rev Mar Sci 3:227-260

Clarke KR (1993) Non-parametric multivariate analyses of changes in community structure. Aust J Ecol 18:117-143

Clarke K, Gorley R (2006) PRIMER v6: user manual/tutorial. Primer-E Ltd, Plymouth

Clarke KR, Warwick RM (2001) A further biodiversity index applicable to species lists: variation in taxonomic distinctness. Mar Ecol Prog Ser 216:265-278

Comiso JC, Parkinson CL, Gersten R, Stock L (2008) Accelerated decline in the Arctic sea ice cover. Geophys Res Lett 35:L01703. doi:10.1029/2007GL031972

Condon RH, Steinberg DK, del Giorgio PA, Bouvier TC, Bronk DA, Graham WM, Ducklow HW (2011) Jellyfish blooms result in a major microbial respiratory sink of carbon in marine systems. Proc Natl Acad Sci USA 108: 10225-10230

> Conley DJ, Malone TC (1992) Annual cycle of dissolved silicate in Chesapeake Bay: implications for the production and fate of phytoplankton biomass. Mar Ecol Prog Ser 81: $121-128$

Crawford RE, Jorgenson JK (1996) Quantitative studies of arctic cod (Boreogadus saida) schools: important energy stores in the arctic food web. Arctic 49:181-193

Cullen JJ, MacIntyre JG (1998) Behavior, physiology and the niche of depth-regulating phytoplankton. In: Anderson DW, Cembella A, Hallegraeff G (eds) Physiological ecology of harmful algal blooms. Springer-Verlag, Heidelberg, p 559-580

Cullen JJ, Franks PS, Karl DM, Longhurst A (2002) Physical influences on marine ecosystem dynamics. In: Robinson AR, McCarthy JJ, Rothschild BJ (eds) The sea, Vol 12. John Wiley \& Sons, New York, NY, p 297-336

Cushing DH (1989) A difference in structure between ecosystems in strongly stratified waters and in those that are only weakly stratified. J Plankton Res 11:1-13

Demers S, Roy S, Gagnon R, Vignault C (1991) Rapid light-induced changes in cell fluorescence and in xanthophyll-cycle pigments of Alexandrium excavatum (Dinophyceae) and Thalassiosira pseudonana (Bacillariophyceae): a photo-protection mechanism. Mar Ecol Prog Ser 76:185-193

> Dmitrenko IA, Polyakov IV, Kirillov SA, Timokhov LA and others (2008) Toward a warmer Arctic Ocean: spreading of the early 21st century Atlantic Water warm anomaly along the Eurasian Basin margins. J Geophys Res 113: C05023. doi: 10.1029/2007JC004158

Environment Canada (2005) MANICE-Manual of standard procedures for observing and reporting ice conditions, revised 9th edn. Canadian Ice Service, Environment Canada, Ottawa, ON

Fenchel T (1988) Marine plankton food chains. Annu Rev Ecol Syst 19:19-38

> Forest A, Sampei M, Makabe R, Sasaki H and others (2008) The annual cycle of particulate organic carbon export in Franklin Bay (Canadian Arctic): environmental control and food web implications. J Geophys Res 113:C03S05. doi:10.1029/2007JC004262

> Forest A, Galindo V, Darnis G, Pineault S, Lalande C, Tremblay JÉ, Fortier L (2011a) Carbon biomass, elemental ratios (C:N) and stable isotopic composition $\left(\delta^{13} \mathrm{C}, \delta{ }^{15} \mathrm{~N}\right)$ of dominant calanoid copepods during the winter-tosummer transition in the Amundsen Gulf (Arctic Ocean). 
J Plankton Res 33:161-178

Forest A, Tremblay JÉ, Gratton Y, Martin J and others (2011b) Biogenic carbon flows through the planktonic food web of the Amundsen Gulf (Arctic Ocean): a synthesis of field measurements and inverse modeling analyses. Prog Oceanogr 91:410-436

Garneau MĖ, Gosselin M, Klein B, Tremblay JÉ, Fouilland E (2007) New and regenerated production during a late summer bloom in an Arctic polynya. Mar Ecol Prog Ser 345:13-26

Geoffroy M, Robert D, Darnis G, Fortier L (2011) The aggregation of polar cod (Boreogadus saida) in the deep Atlantic layer of ice-covered Amundsen Gulf (Beaufort Sea) in winter. Polar Biol 34:1959-1971

Glud RN, Rysgaard S, Kühl M, Hansen JW (2007) The sea ice in Young Sound: implications for carbon cycling. In: Rysgaard S, Glud RN (eds) Carbon cycling in Arctic marine ecosystems. Case study: Young Sound. Medd Grønland. Bioscience 58:62-85

Gosselin M, Levasseur M, Wheeler PA, Horner RA, Booth BC (1997) New measurements of phytoplankton and ice algal production in the Arctic Ocean. Deep-Sea Res II 44: 1623-1644

Grasshoff K, Kremling K, Ehrhardt M (1999) Methods of seawater analysis, 3rd edn. Wiley-VCH, New York, NY

Grebmeier JM, Overland JE, Moore SE, Farley EV and others (2006) A major ecosystem shift in the northern Bering Sea. Science 311:1461-1464

Hansen AS, Nielsen TG, Levinsen H, Madsen SD, Thingstad TF, Hansen BW (2003) Impact of changing ice cover on pelagic productivity and food web structure in Disko Bay, West Greenland: a dynamic model approach. DeepSea Res I 50:171-187

Hill V, Cota G, Stockwell D (2005) Spring and summer phytoplankton communities in the Chukchi and eastern Beaufort Seas. Deep-Sea Res II 52:3369-3385

Howell SEL, Duguay CR, Markus T (2009) Sea ice conditions and melt season duration variability within the Canadian Arctic Archipelago: 1979-2008. Geophys Res Lett 36:L10502. doi:10.1029/2009GL037681

> Hsiao SIC, Foy MG, Kittle DW (1977) Standing stock, community structure, species composition, distribution, and primary production of natural populations of phytoplankton in the southern Beaufort Sea. Can J Bot 55: 685-694

- Ibelings BW, Kroon BMA, Mur LR (1994) Acclimation of photosystem II in a cyanobacterium and a eukaryotic green alga to high and fluctuating photosynthetic photon flux densities, simulating light regimes induced by mixing in lakes. New Phytol 128:407-424

IPCC (Intergovernmental Panel on Climate Change) (2007) Climate change 2007: the physical science basis. Contribution of Working Group 1 to the Fourth Assessment Report of the Intergovernmental Panel on Climate Change. Cambridge University Press, New York, NY

> Juul-Pedersen T, Michel C, Gosselin M (2010) Sinking export of particulate organic material from the euphotic zone in the eastern Beaufort Sea. Mar Ecol Prog Ser 410: $55-70$

Kahru M, Brotas V, Manzano-Sarabia M, Mitchell BG (2011) Are phytoplankton blooms occurring earlier in the Arctic? Glob Change Biol 17:1733-1739.

Karnovsky NJ, Hunt GL Jr (2002) Estimation of carbon flux to dovekies (Alle alle) in the North Water. Deep-Sea Res II 49:5117-5130
Kirchman DL, Moran XAG, Ducklow H (2009) Microbial growth in the polar oceans - role of temperature and potential impact of climate change. Nat Rev Microbiol 7: 451-459

- Klein B, LeBlanc B, Mei ZP, Beret R and others (2002) Phytoplankton biomass, production and potential export in the North Water. Deep-Sea Res II 49:4983-5002

Knap A, Michaels A, Close A, Ducklow H, Dickson A (1996) Protocols for the Joint Global Ocean Flux Study (JGOFS) core measurements. JGOFS Rep No. 19. Reprint of the IOC Manuals and Guides No. 29. UNESCO, Bergen

- Kwok R, Cunningham GF, Wensnahan M, Rigor I, Zwally HJ, Yi D (2009) Thinning and volume loss of the Arctic Ocean sea ice cover: 2003-2008. J Geophys Res 114: C07005. doi:10.1029/2009JC005312

Landry MR, Barber RT, Bidigare RR, Chai F and others (1997) Iron and grazing constraints on primary production in the central equatorial Pacific: an EqPac synthesis. Limnol Oceanogr 42:405-418

Lass S, Spaak P (2003) Chemically induced anti-predator defences in plankton: a review. Hydrobiologia 491: 221-239

> Lavoie D, Denman KL, Macdonald RW (2010) Effects of future climate change on primary productivity and export fluxes in the Beaufort Sea. J Geophys Res 115: C04018. doi:10.1029/2009JC005493

Lean DRS, Burnison BK (1979) An evaluation of errors in the ${ }^{14} \mathrm{C}$ method of primary production measurement. Limnol Oceanogr 24:917-928

Lee SH, Whitledge TE (2005) Primary and new production in the deep Canada Basin during summer 2002. Polar Biol 28:190-197

> Legendre P, Gallagher ED (2001) Ecologically meaningful transformations for ordination of species data. Oecologia 129:271-280

Legendre L, Rassoulzadegan F (1995) Plankton and nutrient dynamics in marine waters. Ophelia 41:153-172

> Legendre L, Demers S, Yentsch CM, Yentsch CS (1983) The ${ }^{14} \mathrm{C}$ method: patterns of dark $\mathrm{CO}_{2}$ fixation and DCMU correction to replace the dark bottle. Limnol Oceanogr 28:996-1003

Legendre L, Gosselin M, Hirche HJ, Kattner G, Rosenberg G (1993) Environmental control and potential fate of sizefractionated phytoplankton production in the Greenland Sea $\left(75^{\circ} \mathrm{N}\right)$. Mar Ecol Prog Ser 98:297-313

Levinsen H, Nielsen TG (2002) The trophic role of marine pelagic ciliates and heterotrophic dinoflagellates in arctic and temperate coastal ecosystems: a cross-latitude comparison. Limnol Oceanogr 47:427-439

> Li WKW, McLaughlin FA, Lovejoy C, Carmack EC (2009) Smallest algae thrive as the Arctic Ocean freshens. Science 326:539

> Lovejoy C, Legendre L, Martineau MJ, Bâcle J, von Quillfeldt CH (2002) Distribution of phytoplankton and other protists in the North Water. Deep-Sea Res II 49: 5027-5047

Lund JWG, Kipling C, Le Cren ED (1958) The inverted microscope method of estimating algal numbers and the statistical basis of estimations by counting. Hydrobiologia 11:143-170

Margalef R (1978) Life forms of phytoplankton as survival alternatives in an unstable environment. Oceanol Acta 1: 493-509

Margalef R, Estrada M, Blasco D (1979) Functional morphology of organisms involved in red tides, as adapted to 
decaying turbulence. In: Taylor DL, Seliger HH (eds) Toxic dinoflagellate blooms. Elsevier, New York, NY, p 89-94

Marie D, Simon N, Vaulot D (2005) Phytoplankton cell counting by flow cytometry. In: Andersen RA (ed) Algal culturing techniques. Academic Press, London, p 253-267

Markus T, Stroeve JC, Miller J (2009) Recent changes in Arctic sea ice melt onset, freezeup, and melt season length. J Geophys Res 114:C12024. doi:10.1029/2009JC 005436

Martin J, Tremblay JÉ, Gagnon J, Tremblay G and others (2010) Prevalence, structure and properties of subsurface chlorophyll maxima in Canadian Arctic waters. Mar Ecol Prog Ser 412:69-84

Martinson D, Iannuzzi RA (1998) Antarctic ocean-ice interactions: implications from ocean bulk property distributions in the Weddell gyre. In: Jeffries MO (ed) Antarctic sea ice: physical processes, interactions and variability. Antarct Res Ser 74:243-271

$>$ McCabe GJ, Clark MP, Serreze MC (2001) Trends in Northern Hemisphere surface cyclone frequency and intensity. J Clim 14:2763-2768

- McLaughlin FA, Carmack EC (2010) Deepening of the nutricline and chlorophyll maximum in the Canada Basin interior, 2003-2009. Geophys Res Lett 37:L24602. doi: 10.1029/2010GL045459

McLaughlin FA, Carmack EC, Williams WJ, Zimmermann S, Shimada K, Itoh M (2009) Joint effects of boundary currents and thermohaline intrusions on the warming of Atlantic water in the Canada Basin, 1993-2007. J Geophys Res 114:C00A12. doi:10.1029/2008JC005001

McPhee MG, Proshutinsky A, Morison JH, Steele M, Alkire MB (2009) Rapid change in freshwater content of the Arctic Ocean. Geophys Res Lett 36:L10602. doi:10.1029/ 2009GL037525

- Michel C, Legendre L, Ingram RG, Gosselin M, Levasseur M (1996) Carbon budget of sea-ice algae in spring: evidence of a significant transfer to zooplankton grazers. J Geophys Res 101:18345-18360

> Michel C, Nielsen TG, Nozais C, Gosselin M (2002) Significance of sedimentation and grazing by ice micro- and meiofauna for carbon cycling in annual sea ice (northern Baffin Bay). Aquat Microb Ecol 30:57-68

Michel C, Ingram RG, Harris LR (2006) Variability in oceanographic and ecological processes in the Canadian Arctic Archipelago. Prog Oceanogr 71:379-401

Mingelbier M, Klein B, Claereboudt MR, Legendre L (1994) Measurement of daily primary production using $24 \mathrm{~h}$ incubations with the ${ }^{14} \mathrm{C}$ method: a caveat. Mar Ecol Prog Ser 113:301-309

- Mostajir B, Gosselin M, Gratton Y, Booth B and others (2001) Surface water distribution of pico- and nanophytoplankton in relation to two distinctive water masses in the North Water, northern Baffin Bay, during fall. Aquat Microb Ecol 23:205-212

> Occhipinti-Ambrogi A (2007) Global change and marine communities: alien species and climate change. Mar Pollut Bull 55:342-352

Parsons TR, Maita Y, Lalli CM (1984) A manual of chemical and biological methods for seawater analysis. Pergamon Press, Toronto, ON

Peterson BJ, Holmes RM, McClelland JW, Vorosmarty CJ and others (2002) Increasing river discharge to the Arctic Ocean. Science 298:2171-2173

Peterson BJ, McClelland J, Curry R, Holmes RM, Walsh JE,
Aagaard K (2006) Trajectory shifts in the Arctic and subarctic freshwater cycle. Science 313:1061-1066

Polovina JJ, Howell EA, Abecassis M (2008) Ocean's least productive waters are expanding. Geophys Res Lett 35: L03618. doi:10.1029/2007GL031745

Polyakov IV, Beszczynska A, Carmack EC, Dmitrenko IA and others (2005) One more step toward a warmer Arctic. Geophys Res Lett 32:L17605. doi:10.1029/2005GL 023740

$>$ Purcell JE, Hopcroft RR, Kosobokova NK, Whitledge TE (2010) Distribution, abundance, and predation effects of epipelagic ctenophores and jellyfish in the western Arctic Ocean. Deep-Sea Res II 57:127-135

Redfield AC, Ketchum BH, Richards FA (1963) The influence of organisms on the composition of seawater. In: Hill MN (ed) The sea, Vol 2. Wiley, New York, NY, p 26-77

Schloss IR, Nozais C, Mas S, van Hardenberg B and others (2008) Picophytoplankton and nanophytoplankton abundance and distribution in the southeastern Beaufort Sea (Mackenzie Shelf and Amundsen Gulf) during fall 2002. J Mar Syst 74:978-993

Serreze MC, Barrett AP, Slater AG, Woodgate RA and others (2006) The large-scale freshwater cycle of the Arctic. J Geophys Res 111:C11010. doi:10.1029/2005JC003424

Shimada $K$, Kamoshida $T$, Itoh $M$, Nishino $S$ and others (2006) Pacific Ocean inflow: influence on catastrophic reduction of sea ice cover in the Arctic Ocean. Geophys Res Lett 33:L08605. doi:10.1029/2005GL025624

> Simpson KG, Tremblay JÉ, Gratton Y, Price NM (2008) An annual study of inorganic and organic nitrogen and phosphorus and silicic acid in the southeastern Beaufort Sea. J Geophys Res 113:C07016. doi:10.1029/2007JC 004462

Sokal RR, Rohlf FJ (1995) Biometry: the principles and practice of statistics in biological research, 3rd edn. WH Freeman, New York, NY

> Rysgaard S, Nielsen TG, Hansen BW (1999) Seasonal variation in nutrients, pelagic primary production and grazing in a high-Arctic coastal marine ecosystem, Young Sound, Northeast Greenland. Mar Ecol Prog Ser 179:13-25

Steinacher M, Joos F, Frölicher TL, Plattner GK, Doney SC (2009) Imminent ocean acidification in the Arctic projected with the NCAR global coupled carbon cycleclimate model. Biogeosciences 6:515-533

> Steinacher M, Joos F, Frölicher TL, Bopp L and others (2010) Projected 21st century decrease in marine productivity: a multi-model analysis. Biogeosciences 7:979-1005

Stirling I (1997) The importance of polynyas, ice edges, and leads to marine mammals and birds. J Mar Syst 10:9-21

Stroeve J, Holland MM, Meier W, Scambos T, Serreze M (2007) Arctic sea ice decline: faster than forecast. Geophys Res Lett 34:L09501. doi:10.1029/2007GL029703

Taucher J, Oschlies A (2011) Can we predict the direction of marine primary production change under global warming? Geophys Res Lett 38:L02603. doi:10.1029/2010GL 045934

ter Braak CJF, Šmilauer P (2002) CANOCO reference manual and CanoDraw for Windows user's guide: software for canonical community ordination (version 4.5). Microcomputer Power, Ithaca, NY

Thomson DH (1982) Marine benthos in the eastern Canadian High Arctic: multivariate analyses of standing crop and community structure. Arctic 35:61-74

Tivy A, Howell SEL, Alt B, McCourt S and others (2011) 
Trends and variability in summer sea ice cover in the Canadian Arctic based on the Canadian Ice Service Digital Archive, 1960-2008 and 1968-2008. J Geophys Res 116:C03007. doi:10.1029/2009JC005855

Tomas CR (1997) Identifying marine phytoplankton. Academic Press, San Diego, CA

Tremblay JÉ, Gagnon J (2009) The effects of irradiance and nutrient supply on the productivity of Arctic waters: a perspective on climate change. In: Nihoul JC, Kostianoy AG (eds) Influence of climate change on the changing Arctic and sub-Arctic conditions. Proceedings of the NATO Advanced Research Workshop. Springer-Verlag, Dordrecht, p 73-94

Tremblay JÉ, Smith WO Jr (2007) Primary production and nutrient dynamics in polynyas. In: Smith WO Jr, Barber DG (eds) Polynyas: windows to the world's oceans. Elsevier, Amsterdam, p 239-270

Tremblay JÉ, Gratton Y, Fauchot J, Price NM (2002) Climatic and oceanic forcing of new, net, and diatom production in the North Water. Deep-Sea Res II 49:4927-4946

Tremblay JÉ, Hattori H, Michel C, Ringuette M and others (2006) Trophic structure and pathways of biogenic carbon flow in the eastern North Water Polynya. Prog Oceanogr 71:402-425

Tremblay JÉ, Simpson K, Martin J, Miller L, Gratton Y, Barber DG, Price NM (2008) Vertical stability and the annual dynamics of nutrients and chlorophyll fluorescence in the coastal, southeast Beaufort Sea. J Geophys Res 113: C07S90. doi:10.1029/2007JC004547

Tremblay G, Belzile C, Gosselin M, Poulin M, Roy S, Tremblay JÉ (2009) Late summer phytoplankton distribution along a $3500 \mathrm{~km}$ transect in Canadian Arctic waters: strong numerical dominance by picoeukaryotes. Aquat Microb Ecol 54:55-70

Tremblay JÉ, Bélanger S, Barber, DG, Asplin M and others (2011) Climate forcing multiplies biological productivity in the coastal Arctic Ocean. Geophys Res Lett 38:L18604. doi:10.1029/2011GL048825

Turner JT, Tester PA (1997) Toxic marine phytoplankton, zooplankton grazers, and pelagic food webs. Limnol Oceanogr 42:1203-1214

van Donk EV, Ianora A, Vos M (2011) Induced defences in marine and freshwater phytoplankton: a review. Hydrobiologia 668:3-19

Editorial responsibility: Graham Savidge, Portaferry, UK
Vaquer-Sunyer R, Duarte CM, Santiago R, Wassmann P, Reigstad M (2010) Experimental evaluation of planktonic respiration response to warming in the European Arctic Sector. Polar Biol 33:1661-1671

> Venrick EL (1988) The vertical distributions of chlorophyll and phytoplankton species in the North Pacific central environment. J Plankton Res 10:987-998

Vetrov AA, Romankevich EA (2009) Production of phytoplankton in the Arctic Seas and its response on recent warming. In: Nihoul JCJ, Kostanoy AG (eds) Influence of climate change on the changing Arctic and sub-Arctic conditions. Springer, Dordrecht, p 95-108

> von Quillfeldt CH (1997) Distribution of diatoms in the Northeast Water Polynya, Greenland. J Mar Syst 10: 211-240

> Wang M, Overland JE (2009) A sea ice free summer arctic within 30 years? Geophys Res Lett 36:L07502. doi: 10.1029/2009GL037820

Wassmann P, Duarte CM, Agustí S, Sejr MK (2011) Footprints of climate change in the Arctic marine ecosystem. Glob Change Biol 17:1235-1249. doi:10.1111/j.13652486.2010.02311.x

Welch HE, Bergmann MA, Siferd TD, Martin KA and others (1992) Energy-flow through the marine ecosystem of the Lancaster Sound region, Arctic Canada. Arctic 45: 343-357

Williams WJ, Carmack EC (2008) Combined effect of windforcing and isobath divergence on upwelling at Cape Bathurst, Beaufort Sea. J Mar Res 66:645-663

Williams WJ, Carmack EC, Ingram RG (2007) Physical oceanography of polynyas. In: Smith WO Jr, Barber DG (eds) Polynyas: windows to the world's oceans. Elsevier, Amsterdam, p 55-85

Yamamoto-Kawai M, McLaughlin FA, Carmack EC, Nishino S, Shimada K, Kurita N (2009) Surface freshening of the Canada Basin, 2003-2007: river runoff versus sea ice meltwater. J Geophys Res 114:C00A05. doi:10.1029/ 2008JC005000

Yang J (2009) Seasonal and interannual variability of downwelling in the Beaufort Sea. J Geophys Res 114:C00A14. doi: 10.1029/2008JC005084

Zhang X, Walsh JE, Zhang J, Bhatt US, Ikeda M (2004) Climatology and interannual variability of Arctic cyclone activity: 1948-2002. J Clim 17:2300-2317

Submitted: May 23, 2011; Accepted: September 1, 2011 Proofs received from author(s): November 4, 2011 